\title{
Activity of zero-valent sulfur in sulfidic natural waters
}

George R Helz

\begin{abstract}
Background: Ionic and molecular carriers of dissolved (filter-passing) zero-valent sulfur $\left(S^{0}\right)$ in anaerobic natural waters include polysulfides, $\mathrm{S}_{n}{ }^{2-}$, molecular $\mathrm{S}_{8}(\mathrm{aq})$, organic macromolecules and certain higher valent thioanions. Because $S^{0}$ is rapidly transferred among these various carriers, its biogeochemical roles in such processes as dehalogenation of organic compounds, chelation of trace metals, and anaerobic microbial metabolism are not determined solely by one ionic or molecular species. Here, $S^{0}$ is treated collectively as a virtual thermodynamic component, and computational as well as graphical methods for quantifying its activity ( $\left.a_{s} 0\right)$ in natural waters are presented. From $\mathrm{a}_{\mathrm{s}} \mathrm{O}$, concentrations of the ionic and molecular carriers of $\mathrm{S}^{0}$ can be calculated easily.

Results: Concentration ratios of any two polysulfide ions define $\mathrm{a}_{s} \mathrm{O}$ (Method I). Unfortunately these concentrations are often too low in nature for accurate quantification with current methods. Measurements of total divalent sulfur $\left(\Sigma S^{-11}\right)$, zero-valent sulfur $\left(\Sigma S^{0}\right)$ and $\mathrm{pH}$ provide a more widely applicable approach (Method II). Systematic errors in $\Sigma S^{0}$ measurements are the main limit to accuracy of this method at the present time. Alternative methods based on greigite solubility and potentiometry are discussed. A critical comparison of Methods I and II reveals inconsistencies at low $\Sigma \mathrm{S}^{0} / \Sigma \mathrm{S}^{-11}$ that imply errors in the thermodynamic data for $\mathrm{HS}_{2}{ }^{-}$and $\mathrm{S}_{2}{ }^{-}$. For samples having low $\Sigma \mathrm{S}^{0} / \Sigma \mathrm{S}^{-11}$, an interim remedy is recommended: letting $\mathrm{pK}_{\mathrm{a} 2}=6.3$ for all $\mathrm{HS}_{\mathrm{n}}{ }^{-}$ions.

Conclusions: Newly assembled data for $a_{S} 0$ in a selection of anaerobic natural waters indicate that $S^{0}$ is always metastable in the surveyed samples with respect to disproportionation to sulfide and sulfate. In all the surveyed environments, sulfur-rich minerals, such as greigite, covellite and orpiment, are stable in preference to their sulfur-poor cohorts, mackinawite, chalcocite and realgar. The $a_{s} \mathrm{O}$ values in the dataset span conditions favoring $\mathrm{Hg}$-polysulfide complexes vs. Hg-sulfide complexes, implying that as $\mathrm{O}$ could affect $\mathrm{Hg}$-methylation rates in nature. No support is found for the common assumption that $\mathrm{a}_{\mathrm{s}} \mathrm{O}=1 \mathrm{in}$ reducing natural waters. This paper calls attention to an urgent need for improved measurement methods, especially for total zero-valent sulfur, as well as new determinations of ionization constants for all $\mathrm{HS}_{n}{ }^{-}$species.
\end{abstract}

Keywords: Polysulfide, Sulfur, Octasulfur, Euxinic basins, Sulfide, Thioanions

\section{Background}

In aquatic and sedimentary environments, sulfur cycles in a series of steps between the +VI $\left(\mathrm{SO}_{4}{ }^{2-}\right)$ and $-\mathrm{II}$ $\left(\mathrm{H}_{2} \mathrm{~S} / \mathrm{HS}^{-}\right)$oxidation states. The reductive part of this cycle $(+\mathrm{VI} \rightarrow-\mathrm{II})$ requires biological mediation at earthsurface conditions and is believed to be accomplished intracellularly with little extracellular leakage of the intermediates in most cases [1]. In contrast, the oxidative part can occur via multiple abiotic and biotic pathways

Correspondence: helz@umd.edu

Chemistry and Biochemistry, University of Maryland, College Park, MD 20742, USA

\section{Chemistry Central}

that progress through various dissolved intermediates [2-4]. The most commonly reported intermediates are zero-valent sulfur, thiosulfate $\left(\mathrm{S}_{2} \mathrm{O}_{3}{ }^{2-}\right)$, and sulfite $\left(\mathrm{SO}_{3}{ }^{2-}\right)$ [5-8]. In aqueous solutions, dissolved molecular zerovalent sulfur occurs almost entirely as $\mathrm{S}_{8}$ [9]. If (and only if) free sulfide is present, dissolved zero-valent sulfur will be found also in polysulfides, $\mathrm{H}_{\mathrm{x}} \mathrm{S}_{\mathrm{n}}{ }^{\mathrm{x}-2}$ ( $\mathrm{x}=0$ to $2, \mathrm{n}=2$ to $>8$ ). In principle, zero-valent $S$ can occur in polythionates $\left(\mathrm{O}_{3} \mathrm{SS}_{\mathrm{n}} \mathrm{SO}_{3}{ }^{2-}, \mathrm{n} \geq 0\right)$ and in organic polysulfides or polysulfanes $\left(\mathrm{RS}_{\mathrm{n}}{ }^{-}, \mathrm{RS}_{\mathrm{n}} \mathrm{R}^{\prime}, \mathrm{n} \geq 2\right.$ ), but in most sulfidic natural waters these contribute negligibly to total dissolved zero-valent sulfur $\left(\Sigma S^{0}\right)[6,10]$. 
Inorganic polysulfides have important functions in nature. By rapidly accepting or donating $\mathrm{S}$ atoms, they buffer the activity of zero-valent sulfur $\left(\mathrm{a}_{S} 0\right)$ :

$$
\mathrm{S}_{\mathrm{n}}{ }^{2-} \leftrightarrow \mathrm{S}_{\mathrm{n}-1}{ }^{2-}+\mathrm{S}^{0} \quad K=\frac{a_{S_{n-1}^{2-}}}{a_{S_{n}^{2-}}}\left(a_{S^{0}}\right)
$$

Here, $\mathrm{S}^{0}$ designates a virtual thermodynamic component, analogous to $\mathrm{e}^{-}$, which is the conceptual basis of the well-known $\mathrm{pE}$ scale. The standard state for the $\mathrm{S}^{0}$ component is chosen so that $\mathrm{a}_{\mathrm{S}} \mathrm{O}=1$ at any temperature and $10^{5} \mathrm{~Pa}$ pressure in a system at equilibrium with rhombic sulfur. Then, $a_{S} 0>1$ implies supersaturation and $a_{S} 0<1$ implies undersaturation of the system with rhombic sulfur. The value of $\mathrm{a}_{S} 0$ is not linked to the concentration of a specific ion or molecule in solution. Instead, it is a continuous thermodynamic property that is controlled collectively by the assemblage of ions and molecules that participate in rapid, reversible $\mathrm{S}$-atom transfer reactions. Consistent with much qualitative earlier evidence [11], Kamyshny et al. [12] demonstrated that S-atom transfer among polysulfide ions occurs with a characteristic equilibration time of $\sim 10$ s. Consequently, polysulfide species can never stray far from equilibrium with one another in the laboratory or the field, and the value of $\mathrm{a}_{S} 0$ will always be physically welldefined (buffered) in solutions that contain polysulfides as the dominant $S^{0}$ carriers. In this respect, $a_{S} 0$ differs from $\mathrm{a}_{\mathrm{e}-}$ (i.e. $10^{-\mathrm{pE}}$ ), which can be poorly defined in both in the laboratory and the field because $\mathrm{e}^{-}$-transfer reactions are often sluggish, and various redox couples in natural waters can be far from equilibrium with one another $[13,14]$. As discussed in more detail in Section A of the Additional file 1, buffering of $\mathrm{a}_{\mathrm{S}} 0$ in an aqueous phase by rapid equilibration among polysulfides does not imply or require that polysulfides equilibrate rapidly with particulate phases of sulfur; indeed, owing to slow heterogeneous equilibration rates, the value of $\mathrm{a}_{\mathrm{S}} 0$ in the aqueous phase of a rhombic sulfur suspension is not necessarily unity.

This paper concerns methods for quantifying $a_{S} 0$ in natural waters. No tool exists for measuring as 0 directly (e.g. a tool analogous to the glass electrode for measuring $\left.\mathrm{a}_{\mathrm{H}+}\right)$, so $\mathrm{a}_{\mathrm{S}} \mathrm{O}$ must be quantified through thermodynamic modeling. Although experimentalists often employ $a_{S} 0$ to describe $S^{0}$-dependent processes in the laboratory, $\mathrm{a}_{\mathrm{S}} \mathrm{O}$ rarely has been determined in sulfidic natural waters. (Among experimentalists in such fields as mineralogy, economic geology and hydrothermal geochemistry, the fugacity of $\mathrm{S}_{2}(\mathrm{~g})\left(\mathrm{f}_{\mathrm{S} 2}\right)$ has been widely used as an alternate measure of $a_{S} 0$ [15]; at $298^{\circ} \mathrm{K}$ the relationship between these variables is $\mathrm{a}_{\mathrm{S}} \mathrm{O}=$ $10^{6.95} \mathrm{f}_{\mathrm{S} 2}{ }^{1 / 2}$.)
Knowledge of $a_{S} 0$ in natural waters is important primarily for two reasons. First, $a_{s} 0$ itself influences the behavior of other elements in nature and constrains the metabolic energy available from microbial oxidation, disproportionation or reduction of zero-valent sulfur. The electric potential available from seafloor fuel cells also depends among other things on as 0 in pore waters [16].

In mineral pairs whose compositions differ only in $\mathrm{S}$ content (e.g. chalcocite $\left(\mathrm{Cu}_{2} \mathrm{~S}\right)$ - covellite $(\mathrm{CuS})$, realgar $(\mathrm{AsS})$ - orpiment $\left(\mathrm{As}_{2} \mathrm{~S}_{3}\right)$ or mackinawite $(\mathrm{FeS})$ - greigite $\left.\left(\mathrm{Fe}_{3} \mathrm{~S}_{4}\right)\right)$, as 0 determines which mineral is thermodynamically favored. Even among minerals with nominally the same composition, such as cinnabar - metacinnabar (both $\mathrm{Hg}_{1-\mathrm{x}} \mathrm{S}$ ), small differences in non-stoichiometry make $\mathrm{a}_{\mathrm{S}} \mathrm{O}$ a possible determinant of which phase is expected to form and persist in nature $[17,18]$. Among thioanions of $\mathrm{As}, \mathrm{Sb}$ and Mo (and probably others), the ratios of oxidized to reduced forms are regulated in sulfidic solutions by as 0 as well as $\mathrm{a}_{\mathrm{H}}+[19-22]$. For example:

$$
\mathrm{H}_{2} \mathrm{As}^{\mathrm{III}} \mathrm{S}_{3^{-}}+\mathrm{S}^{0} \leftrightarrow \mathrm{As}^{\mathrm{V}} \mathrm{S}_{4}{ }^{3-}+2 \mathrm{H}^{+} \quad K \frac{a_{S^{0}}}{a_{H^{+}}^{2}}=\frac{a_{A s S_{4}^{3-}}}{a_{H_{2} A s S_{3}^{-}}}
$$

Because of reactions of this type, higher valent thioanions of $\mathrm{As}$ and $\mathrm{Sb}$, just like polysulfides, must be regarded as carriers of $S^{0}$ in solution. Notice that addition of one $S^{0}$ atom to the non-bonding electron pair in As(III) accomplishes the equivalent of a $2 \mathrm{e}^{-}$oxidation, making $\mathrm{S}^{0}$-atom transfer an alternate redox mechanism to $\mathrm{e}^{-}$transfer.

The second principal reason why knowledge of $\mathrm{a}_{\mathrm{S}} 0$ in natural waters is needed is that along with $\mathrm{pH}$ and $\mathrm{a}_{\mathrm{HS}}-$, it can be used to predict polysulfide chain length distributions. An example of chain length's importance is its effect on trace metal chelation by polysulfides; only $\mathrm{S}_{\mathrm{n}}{ }^{2-}$ ions having $n \geq 4$ are able to form chelate rings. In sulfidic waters, chelation by polysulfides is likely to influence strongly the mobility, bioavailability and toxicity of Class b, or soft metal cations $\left(\mathrm{Cu}^{+}, \mathrm{Ag}^{+}, \mathrm{Au}^{+}\right.$and $\left.\mathrm{Hg}^{2+}\right)$ [18,23-28]. Another example involves polysulfide-dependent kinetic processes. Explaining the reactivity of polysulfides requires accounting for variations in chain length in response to solution composition [29]. Polysulfide reactivity can control lifetimes of many xenobiotic organic compounds in anoxic environments [30-37].

Previously, a convenient graphical approach for determining as 0 in laboratory and field samples was presented [38], but this graph is out of date because of major revisions of the thermodynamic data [39-41]. The goals of this paper are threefold: 1) to review computational methods and to update graphs for estimating $\left.a_{S} 0,2\right)$ to survey current information about $\mathrm{a}_{\mathrm{S}} 0$ in modern sulfidic water 
bodies and 3) to explore briefly what this information might imply about biogeochemical processes.

\section{Quantifying as 0}

Method I. Estimating $a_{S} 0$ from measurements of two polysulfide ion concentrations. During the last decade, development of a fast derivatization method has enabled for the first time measurement of individual inorganic polysulfide ion concentrations in natural waters [42]. When pairs of such ions are abundant enough to be measured, $\mathrm{a}_{\mathrm{S}} \mathrm{O}$ is accessible by a very simple calculation provided $\mathrm{pH}$ is high enough that protonation of $\mathrm{S}_{\mathrm{n}}{ }^{2-}$ ions can be ignored. If the formation of a polysulfide ion is represented as follows,

$$
\mathrm{HS}^{-}+(\mathrm{n}-1) \mathrm{S}^{0} \leftrightarrow \mathrm{H}^{+}+\mathrm{S}_{\mathrm{n}}{ }^{2-} \quad K_{n}=\frac{10^{-p H} a_{S_{n}^{2-}}}{a_{H S^{-}}\left(a_{S^{0}}\right)^{(n-1)}}
$$

then for two polysulfide ions that differ in composition by $\Delta \mathrm{n}\left(\mathrm{S}^{0}\right)$ atoms, i.e. $\mathrm{S}_{\mathrm{n}}{ }^{2-}$ and $\mathrm{S}_{\mathrm{n}+\Delta \mathrm{n}}{ }^{2-}$ :

$$
\frac{\left[S_{n+\Delta n}^{2-}\right]}{\left[S_{n}^{2-}\right]} \approx \frac{a_{S_{n+\Delta n}^{2-}}}{a_{S_{n}^{2-}}}=\frac{K_{n+\Delta n}}{K_{n}}\left(a_{S^{0}}\right)^{\Delta n}
$$

Where $[\mathrm{x}]$ and $\mathrm{a}_{\mathrm{x}}$ respectively represent the molar concentration and activity of species $x$. Based on this equation, Figure 1 graphically presents relationships between $a_{S} 0$ and ratios of those polysulfide ions that are usually most abundant and thus most easily measured.

If as 0 indicated in Figure 1 falls inside the hatched area $\left(\mathrm{a}_{\mathrm{s}} 0\right.$ above $\approx 1.22$ ), then the sample is supersaturated

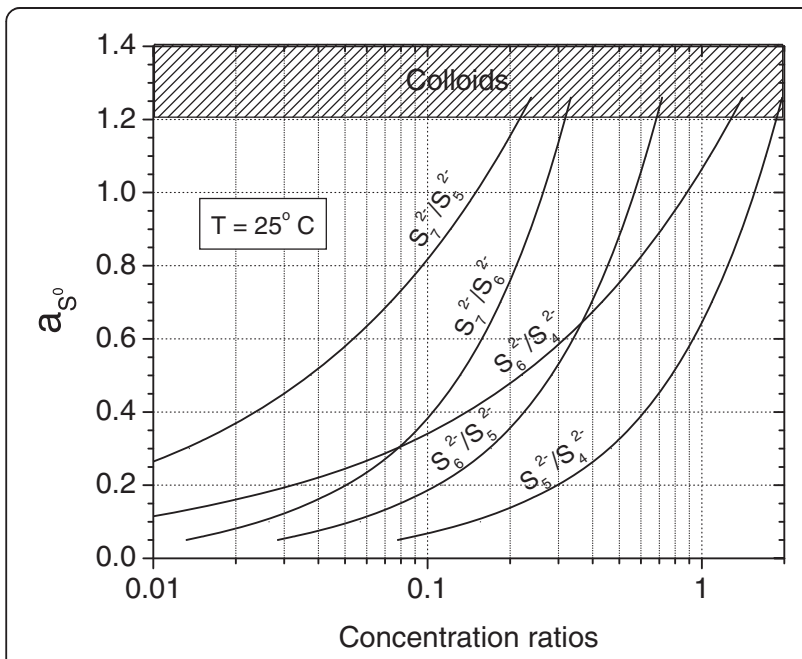

Figure 1 Relationship of $\mathrm{a}_{\mathrm{s}} \mathrm{O}$ to ratios of polysulfide ion concentrations. The hatched region demarks $\mathrm{a}_{\mathrm{s}} \mathrm{O}$ values that are unattainable, except transiently, because rapid precipitation of inorganic colloids occurs. The curves are independent of $\mathrm{pH}$ provided $\mathrm{pH}$ is high enough that polysulfide ions are not appreciably protonated. with respect to colloidal sulfur, which will precipitate at least initially as nanoscale, supercooled droplets of liquid sulfur $[43,44]$. The value of 1.22 is based on an experimental determination of the solubility of colloidal sulfur [27]. Older experiments that defined the kinetic threshold for rapid colloid precipitation suggest a similar value [43]. The true position of the colloid boundary in natural waters is somewhat uncertain owing to the possibility that natural organic macromolecules could affect its position. Additionally, the temperature and colloid-size dependences of this boundary are not known. It should be emphasized that $a_{S} 0<1.22$ does not prove absence of colloids. Colloids have been observed in highly dynamic systems when $a_{S} 0<1.0$ [45]. Possibly these colloids were produced by bacterial sulfide oxidation, which generates colloidal sized, chemically stabilized $\mathrm{S}^{0}$-containing substances that are less soluble than abiotic colloids [10,46,47].

This approach to quantifying as 0 is attractive because activity coefficients of the polysulfide ions reasonably can be assumed to cancel, as done in equation 4, making ionic strength irrelevant. Furthermore, the $K_{n+\Delta n} / K_{n}$ ratio changes slowly with temperature, so in many cases temperature also can be neglected. When $a_{s} 0$ has been determined from equation 4, back substitution into equation 3 yields $\mathrm{a}_{\mathrm{HS}-}$, and these two quantities in turn enable calculation of all polysulfide ion concentrations as well as the concentration of $\mathrm{S}_{8}(\mathrm{aq})$ in a sample of known $\mathrm{pH}$, ionic strength and temperature. On the other hand, a weakness of this method is its sensitivity to analytical error, as discussed later. In practice, this approach has enjoyed only limited application, because in many samples individual polysulfide concentrations are too small for direct quantification.

Method II. Estimating $a_{S} \mathrm{O}$ from measurements of $\mathrm{pH}$, $\Sigma S^{O}$ and $\Sigma S^{-I I}$. A more widely applicable approach employs thermodynamic modeling based on measurements of $\mathrm{pH}$, total dissolved inorganic sulfide $\left(\Sigma \mathrm{S}^{-\mathrm{II}}\right)$ and total dissolved zero-valent sulfur $\left(\Sigma S^{0}\right)$. Computational methods for implementation of this method have been described previously $[10,27,38]$. A description of the approach is given in the Additional file 1 , Section $B$. If $S_{8}$ and all polysulfides are in equilibrium with one another owing to rapid S-atom transfer reactions, then equation 5 expresses the relationship between dissolved $\Sigma \mathrm{S}^{0}$, $\mathrm{a}_{\mathrm{HS} \text {-, }}$ and $\mathrm{pH}$.

$$
\begin{aligned}
\Sigma S^{0}= & 8\left[\frac{\left(a_{S^{0}}\right)^{8} K_{0}}{\gamma_{0}}\left(1+K_{p}(D O C)\right)\right] \\
& +\left(a_{H S^{-}}\right) \sum_{n=2}^{8}\left[\frac{(n-1)\left(K_{n} a_{S^{0}}^{(n-1)}\right)}{10^{-p H}}\left(\frac{1}{\gamma_{2}}+\frac{10^{-p H}}{K_{n a 2} \gamma_{1}}+\frac{10^{-2 p H}}{K_{n a 1} K_{n a 2} \gamma_{0}}\right)\right]
\end{aligned}
$$


Here, $\gamma_{q}$ represents the ionic activity coefficient of a species having charge $\pm q$ ); $\gamma_{0}$, represents the activity coefficient of an uncharged species such as dissolved molecular $\mathrm{S}_{8}$ or $\mathrm{H}_{2} \mathrm{~S}_{\mathrm{n}}$, and the various stability constants are defined in Section $\mathrm{C}$ of the Additional file 1.

The first term in brackets in equation 5 accounts for dissolved (filter passing) $\mathrm{S}_{8}$ both in true solution and physically sorbed to filter-passing organic macromolecules (DOC). Owing to its hydrophobic character, $\mathrm{S}_{8}$ is expected to associate physically with dissolved organic macromolecules just as hydrophobic pesticides and similar compounds do [10,48]. The second term is not meant to account for covalently bound organic $S$, which usually is excluded from dissolved $\Sigma S^{0}$ by the analytical procedure. Probably, the second term oversimplifies the mechanisms by which DOC can affect $S^{0}$ behavior, but it represents a reasonable description given the current level of knowledge. Synthetic surfactants at concentrations above their critical micelle concentration (CMC) are known to solubilize $S^{0}$ in the same way that they solubilize fats [49]. This mechanism is neglected in Equation 5 because current estimates of the CMC for natural organic matter [50] suggest that DOC rarely achieves sufficient concentrations to form micelles.

Evaluation of $\mathrm{a}_{\mathrm{S}} \mathrm{O}$ for a natural water sample involves finding the root of equation 5 , which is an eighth order polynomial, given the temperature, ionic strength, $\Sigma \mathrm{S}^{0}$, $\mathrm{pH}$, and $\mathrm{a}_{\mathrm{HS} \text {. }}$ Unless $\Sigma \mathrm{S}^{0}<<\Sigma \mathrm{S}^{-\mathrm{II}}$, evaluating $\mathrm{a}_{\mathrm{HS} \text { - requires }}$ a correction for $\mathrm{S}^{-\mathrm{II}}$ contained in polysulfides. This can be obtained from:

$$
\begin{aligned}
\Sigma S^{-I I}= & \left(a_{H S^{-}}\right)\left\{\left(\frac{1}{\gamma_{1}}+\frac{10^{-p H}}{K_{a 1} \gamma_{0}}\right)\right. \\
& \left.+\sum_{n=2}^{8}\left[\frac{K_{n} a_{S^{0}}^{(n-1)}}{10^{-p H}}\left(\frac{1}{\gamma_{2}}+\frac{10^{-p H}}{K_{n a 2} \gamma_{1}}+\frac{10^{-2 p H}}{K_{n a 1} K_{n a 2} \gamma_{0}}\right)\right]\right\}
\end{aligned}
$$

Equations 5 and 6 can be solved numerically for $a_{S} 0$ using tools such as SOLVER in EXCEL, but the labor of setting the problem up is considerable. Fortunately, it will often be the case, especially in neutral to alkaline sulfidic waters, that the amount of $\Sigma S^{0}$ contributed by free and sorbed molecular $\mathrm{S}_{8}$ is negligible. An upper limit to free $\left[\mathrm{S}_{8}\right]$ is about $\approx 0.13 \mu \mathrm{M}$ (equivalent to $\sim 1 \mu \mathrm{M}$ as $\mathrm{S}^{0}$ ) because of rapid colloidal $S^{0}$ precipitation above that level $[10,27,43]$. If the terms accounting for free and sorbed $S_{8}$ in equation 6 can be neglected, then dividing equation 5 by equation 6 yields an expression that is independent of $\mathrm{a}_{\mathrm{HS}-}$ :

$$
\frac{\Sigma S^{0}}{\Sigma S^{-I I}}=\frac{\sum_{n=2}^{8}\left[\frac{(n-1)\left(K_{n} a_{5^{0}}^{(n-1)}\right)}{10^{-p H}}\left(\frac{1}{\gamma_{2}}+\frac{10^{-p H}}{K_{n a 2} \gamma_{1}}+\frac{10^{-2 p H}}{K_{n a 2} K_{n a 1} \gamma_{0}}\right)\right]}{\left\{\left(\frac{1}{\gamma_{1}}+\frac{10^{-p H}}{K_{a 1} \gamma_{0}}\right)+\sum_{n=2}^{8}\left[\frac{K_{n} a_{50}^{(n-1)}}{10^{-p H}}\left(\frac{1}{\gamma_{2}}+\frac{10^{-p H}}{K_{n a 2} \gamma_{1}}+\frac{10^{-2 p H}}{K_{n a 2} K_{n a 1} \gamma_{0}}\right)\right]\right\}}
$$

This equation can be solved for $\mathrm{a}_{\mathrm{S}} \mathrm{O}$ values at a given temperature and ionic strength from only two input quantities, $\mathrm{pH}$ and the measured $\Sigma \mathrm{S}^{0} / \Sigma \mathrm{S}^{-\mathrm{II}}$ ratio. In consequence, 2-D contour plots suffice to present graphical solutions, as done in Figures 2 and 3. (Enlarged versions of these figures are given in Section D of the Additional file 1 for the convenience of readers who might wish to use them to obtain quick approximations of $\mathrm{a}_{\mathrm{S}} \mathrm{O}$ in field or laboratory samples.) Estimates of $\mathrm{a}_{\mathrm{S}} 0$ open the way to computing $\left[\mathrm{S}_{8}\right]$ and the concentrations of all polysulfide species very easily by back substitution into equation 6 and the equilibrium constant expressions. If this procedure reveals that $\left[\mathrm{S}_{8}\right]$ is not negligible relative to measured $\Sigma S^{0}$, then the approximation inherent in equation 7 is invalid, and $a_{S} 0$ must be obtained by a full numerical solution of equations 5 and 6 .

Currently, the accuracy of Method II is probably limited chiefly by problems in measuring $\Sigma S^{0}$. Method II will overestimate as 0 if the $\Sigma S^{0}$ analysis includes contributions from species other than polysulfides and $S_{8}$ in its free and DOC-sorbed states. Colloidal $S^{0}$ is a potential problem in most analytical approaches [7]. Colloids are apt to be more problematic in fresh than saline waters, because hydrophobic particles coagulate rapidly under saline conditions [51]. In fresh as well as saline

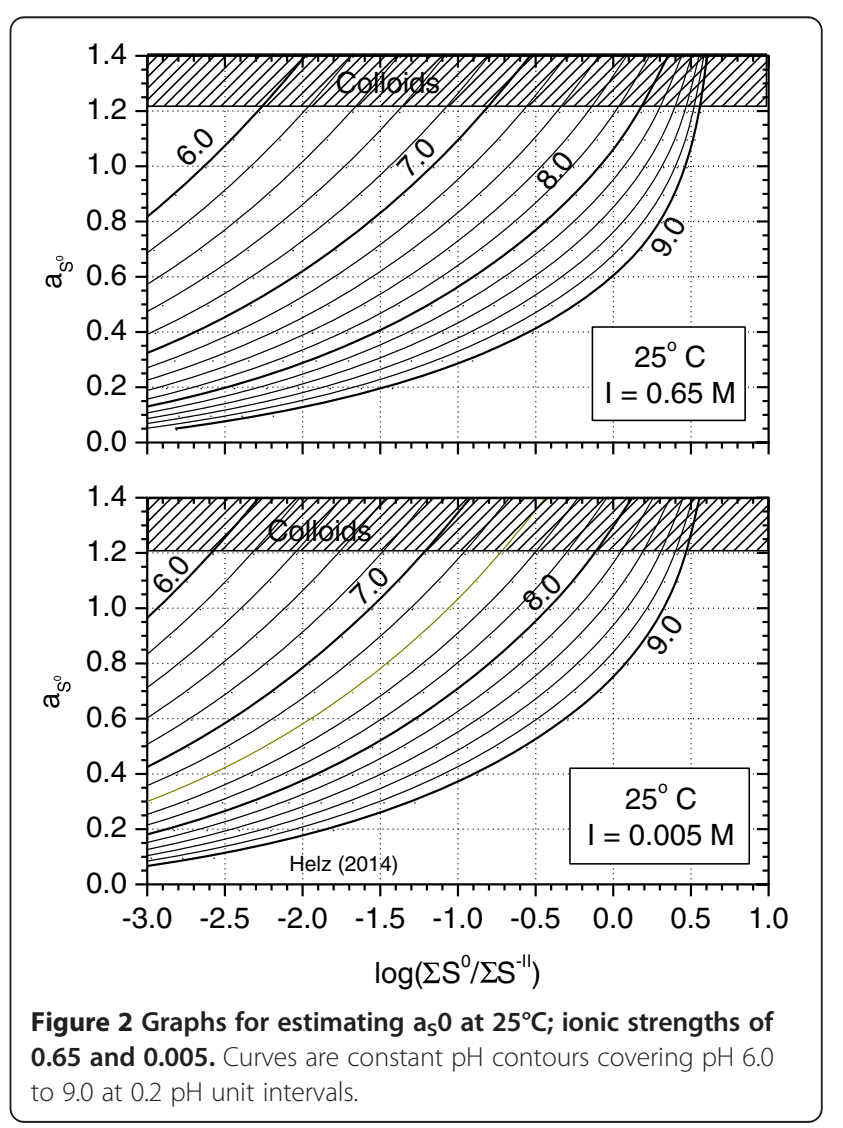




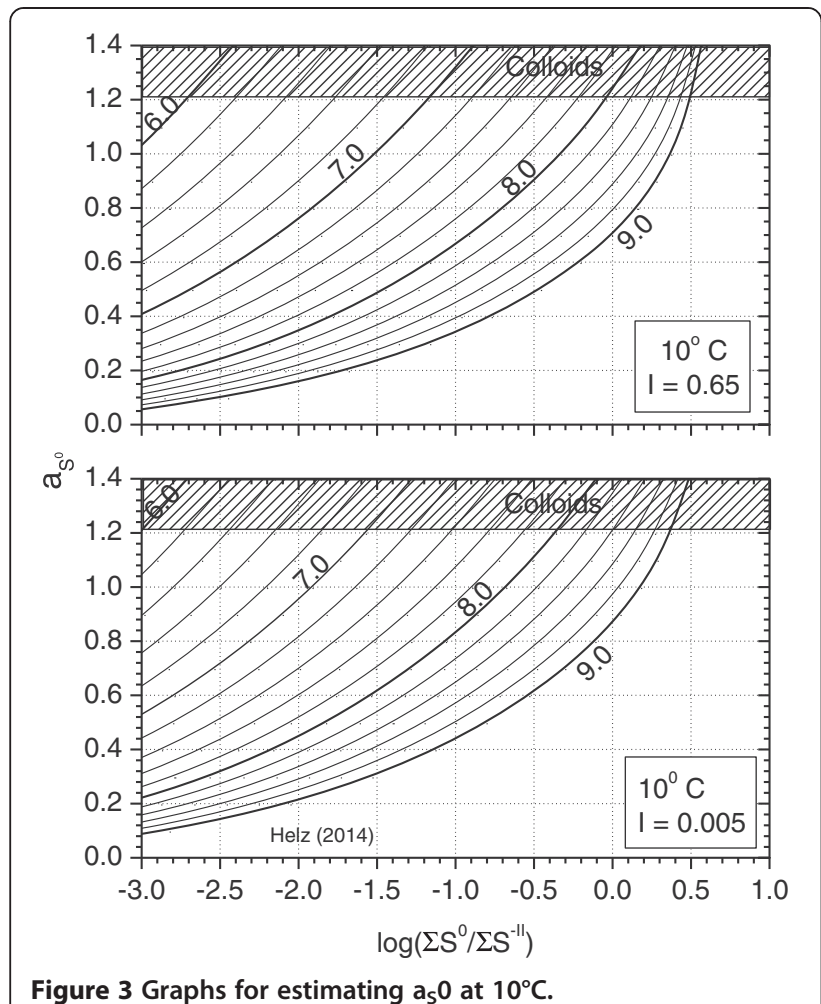

Figure $3 \mathrm{Graphs}$ for estimating $\mathrm{a}_{\mathrm{s}} \mathrm{O}$ at $10^{\circ} \mathrm{C}$.

waters, artifacts due to colloids can be minimized by using dialysis sampling methods [27].

Critical comparison of Methods I \& II. In a recent study of ground water from wells in Israel, three to four polysulfide ion concentrations were measured directly, and $\Sigma S^{0}$ was measured by three independent approaches [52]. This rich data set affords an extraordinary opportunity to test Methods I and II against one another and to explore uncertainties. Two wells (Kfar Urya 8 and Tzofar 221) were selected because three independent measurements of $\Sigma S^{0}$ in their waters were reasonably consistent and because their waters differed greatly in $\Sigma \mathrm{S}^{0} / \Sigma \mathrm{S}^{-\mathrm{II}}$ ratio. In Section $\mathrm{E}$ of the Additional file $1, \mathrm{a}_{\mathrm{S}} 0$ as well as the concentrations of $\mathrm{S}_{8}(\mathrm{aq})$ and a number of $\mathrm{H}_{\mathrm{x}} \mathrm{S}_{\mathrm{n}}{ }^{\mathrm{x}-2}$ species have been calculated in multiple ways for the two wells using alternate choices of input data.

For Kfar Urya 8 water, in which $\Sigma \mathrm{S}^{0} / \Sigma \mathrm{S}^{-\mathrm{II}}=0.2$, Additional file 1: Table S-2 reveals a level of agreement in the output from the three models based on Method I and the three models based on Method II that seems reasonable in the light of analytical uncertainties. On the other hand, Tzofar 221 waters, which had $\Sigma S^{0} / \Sigma S^{-I I}=0.009$, yield wildly discrepant values from seven independent models.

The problem with the Tzofar 221 data is illustrated in Figure 4A based on the numerical values in Additional file 1: Table S-3A. The desired pattern in Figure 4 would consist of nearly horizontal lines connecting roughly

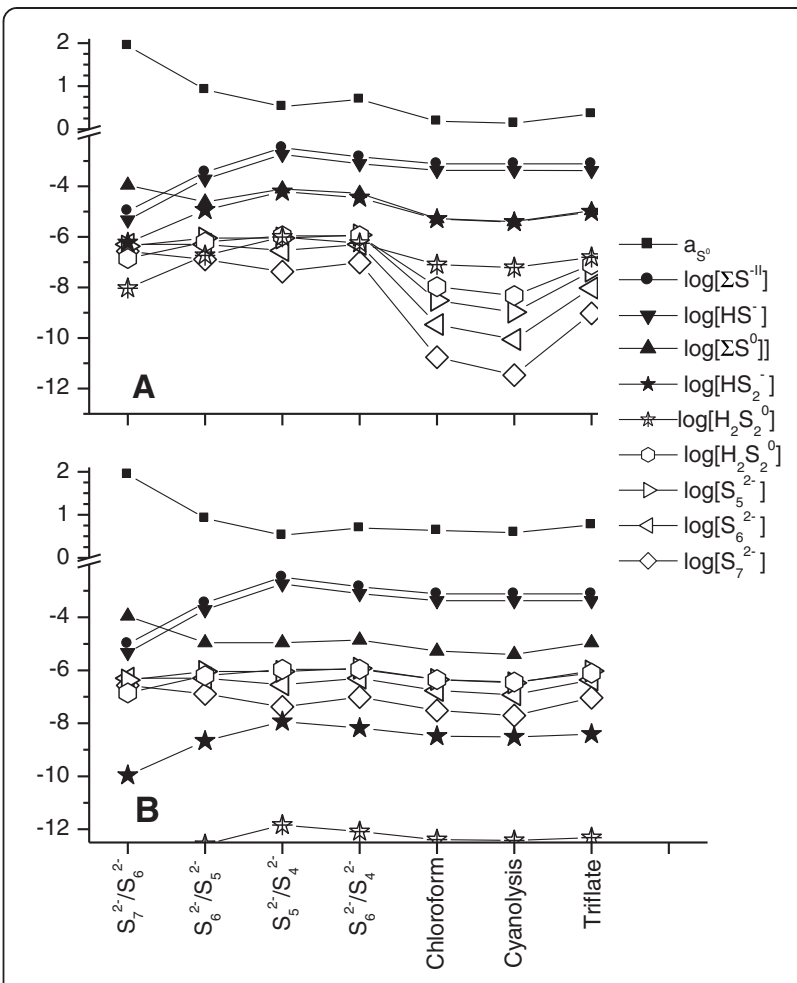

Figure 4 Comparison of output from four Method I and three Method II models. Data are from [52] for the Tsofar 221 well $\left(\mathrm{pH}=6.81, \mathrm{I}=0.041, \mathrm{~T}=38^{\circ} \mathrm{C}\right)$. Labels on the horizontal axis indicate the choices of input data for each of the seven calculations; different pairs of polysulfide species were used in the case of Method I. $\Sigma \mathrm{S}^{0}$ values measured in different ways were used for Method II (the same $\Sigma \mathrm{S}^{-11}$ was used in all Method II models). In the upper graph, thermodynamic data used in the computations were taken from [39-41] for $\mathrm{S}_{8}(\mathrm{aq})$. In the lower graph, $\mathrm{pK}_{\text {na1 }}$ for all $\mathrm{H}_{2} \mathrm{~S}_{n}{ }^{0}$ species was set to 3.0 and $\mathrm{pK}_{\mathrm{na} 2}$ for all $\mathrm{HS}_{\mathrm{n}}{ }^{-}$species was set to 6.3. Numerical values on which this figure is based are given in Table S-3.

identical concentrations calculated from each of the seven speciation models tested. The actual pattern is quite different. Values of as 0 range from 2.04 by Method I using $\mathrm{S}_{7}{ }^{2-}$ and $\mathrm{S}_{6}{ }^{2-}$ concentrations as input down to 0.13 by Method II using $\Sigma S^{0}$ determined by cyanolysis and $\Sigma \mathrm{S}^{\text {-II }}$ determined by methylene blue. Because of this large range in $a_{S} 0, \Sigma S^{-I I}$ calculated by Method I ranges from 3000 to $10 \mu \mathrm{M}$, compared to the actual value of $770 \pm 38 \mu \mathrm{M}$ determined by methylene blue. Similarly, $\Sigma S^{0}$ calculated by Method I ranges from 166 down to $22 \mu \mathrm{M}$, compared to actual values from 11 to $4 \mu \mathrm{M}$ determined by three independent analytical methods. The concentrations of $\mathrm{S}_{4}{ }^{2-}, \mathrm{S}_{5}{ }^{2-}, \mathrm{S}_{6}{ }^{2-}$ and $\mathrm{S}_{7}{ }^{2-}$ calculated by Method II using chloroform extraction and cyanolysis data for $\Sigma S^{0}$ are uniformly below $0.01 \mu \mathrm{M}$ whereas actual values measured by methyl triflate derivatization are more than 10-fold higher. Clearly, at low $\Sigma \mathrm{S}^{0} / \Sigma \mathrm{S}^{-\mathrm{II}}$ these thermodynamic models have gone seriously awry; for some variables, the alternate models are inconsistent at the order of magnitude level. 
Close inspection of the results reveals two general problems. The first lies in the thermodynamic data. It is apparent from Figure 4A that concentrations of $\mathrm{HS}_{2}{ }^{-}$ and $\mathrm{H}_{2} \mathrm{~S}_{2}{ }^{0}$ are much too large and dominate dissolved $\Sigma \mathrm{S}^{0}$ at near-neutral $\mathrm{pH}$ when $\Sigma \mathrm{S}^{0} / \Sigma \mathrm{S}^{-\mathrm{II}}$ is very low. In Method I, where $\mathrm{S}_{4}{ }^{2-}$ to $\mathrm{S}_{7}{ }^{2-}$ concentrations are constrained by measurements, the effect of this is to make calculated $\Sigma S^{0}$ values too large relative to measurements because of the additional $\mathrm{S}^{0}$ contained in $\mathrm{HS}_{2}{ }^{-}$and $\mathrm{H}_{2} \mathrm{~S}_{2}{ }^{0}$. In Method II, where $\Sigma \mathrm{S}^{0}$ is constrained by measurements, high $\mathrm{HS}_{2}{ }^{-}$and $\mathrm{H}_{2} \mathrm{~S}_{2}{ }^{0}$ concentrations force $\mathrm{a}_{\mathrm{S}} \mathrm{O}$ downward and make concentrations of $\mathrm{S}_{4}{ }^{2-}$ to $\mathrm{S}_{7}{ }^{2-}$ much too small relative to measurements in order to preserve the $\Sigma S^{0}$ molar balance.

That thermodynamic data for $\mathrm{HS}_{2}{ }^{-}$and $\mathrm{H}_{2} \mathrm{~S}_{2}{ }^{0}$ might be problematic should not be surprising. Current free energies of formation of $\mathrm{HS}_{2}{ }^{-}$and $\mathrm{H}_{2} \mathrm{~S}_{2}{ }^{0}$ rely on a $\Delta \mathrm{G}_{\mathrm{f}}{ }^{0}$ value for $\mathrm{S}_{2}{ }^{2-}$ that has much greater uncertainty than for the other $\mathrm{S}_{\mathrm{n}}{ }^{2-}$ ions [39]. They also rely on $\mathrm{pK}_{\mathrm{a}}$ values that were not measured, but extrapolated from measurements on $\mathrm{S}_{4}{ }^{2-}$ and $\mathrm{S}_{5}{ }^{2-}$ [53]. In the extrapolation, $\mathrm{pK}_{\mathrm{a}}$ values were correlated to reciprocal chain length, $\mathrm{n}^{-1}$, where $\mathrm{n}$ is the number of $\mathrm{S}$ atoms in $\mathrm{H}_{\mathrm{x}} \mathrm{S}_{\mathrm{n}}{ }^{\mathrm{x}-2}$ species. This extrapolation method is thrown into doubt by a recent theoretical study which suggests that correlation to $\mathrm{n}^{0}$ would be more appropriate [54]. Correlating $\mathrm{pK}_{\mathrm{a}}$ values to $\mathrm{n}^{0}$ rather than $\mathrm{n}^{-1}$ lowers the ionization constant of $\mathrm{HS}_{2}{ }^{-}$by about four orders of magnitude, greatly diminishing the stabilities of both $\mathrm{HS}_{2}{ }^{-}$and $\mathrm{H}_{2} \mathrm{~S}_{2}{ }^{0}$.

In Figure $4 \mathrm{~B}, \mathrm{pK}_{\mathrm{a} 2}$ for all $\mathrm{HS}_{\mathrm{n}}{ }^{-}$species has been set to 6.3 , the average of the measurements for $\mathrm{S}_{4}{ }^{2-}$ and $\mathrm{S}_{5}{ }^{2-}$. This choice is consistent with the finding in [54] that $\mathrm{pK}_{\mathrm{a} 2}$ values are nearly independent of $\mathrm{n}$, but it is inconsistent with the finding in the same paper that $\mathrm{pK}_{\mathrm{a} 2} \approx 9.4$ at all $\mathrm{n}$. Such high $\mathrm{pK}_{\mathrm{a} 2}$ values are rejected here because they contradict experimental evidence [53,55]. Figure 4B and Additional file 1: Table S-2B show that greatly improved agreement is achieved with this $\mathrm{pK}_{\mathrm{a}}$ change; only the first two Method I models remain in substantial disagreement.

The second general problem, which explains the remaining disagreement, arises simply from analytical error associated with Method I. In Additional file 1: Table S-4, this is demonstrated by error propagation calculations. It is clear in that table that the precision achieved by Method II is far better than the precision achieved by Method I. However this conclusion must be qualified in two ways. First, Method I precision is impaired in this example because the concentrations of individual polysulfide ions were not far above their detection limits, and thus subject to large relative analytical uncertainty. Method I can be expected to perform better in samples having $\Sigma S^{0}$ substantially above $10^{-5} \mathrm{M}$. Second, the excellent precision (a measure of random error) of Method II in this example ignores the abovementioned systematic error in $\Sigma S^{0}$ determinations. As shown in Additional file 1: Table S-3 (and more extensively in [52]), $\Sigma \mathrm{S}^{0}$ measured by alternate methods varies by nearly 4-fold, giving rise to a similar range in most of the concentrations calculated by Method II. This large range in $\Sigma S^{0}$ lies outside reasonable estimates of measurement uncertainty, testifying to existence of systematic errors in determinations of $\Sigma \mathrm{S}^{0}$.

Kamyshny and coworkers $[45,52]$ have used a modified Method I approach to calculate what they call the relative saturation level (RSL), which is identical to $a_{S} 0$. They controlled the analytical error problem by a weighted regression method that combines data from several polysulfide ion ratios. For Tzofar 221, their value for RSL $\left(a_{S} 0\right)$ is $0.70 \pm 0.12$, which agrees within uncertainty with $0.63 \pm 0.02$ by Method II using $\Sigma S^{0}$ from chloroform extraction (Additional file 1: Table S-4) or $0.59 \pm 0.03$ using $\Sigma S^{0}$ from cyanolysis.

Improvements in measuring $\Sigma \mathrm{S}^{0}$, as well as in $\mathrm{pK}_{\mathrm{a}}$ data for polysulfides, are urgently needed. However until better measurements become available, assigning $\mathrm{pK}_{\text {na1 }}=3$ and $\mathrm{pK}_{\mathrm{na} 2}=6.3$ uniformly to all polysulfides seems to be a pragmatic remedy for the disagreement demonstrated in Figure 4. This remedy has been adopted throughout this paper, including in Figures 2 and 3. The entire thermodynamic data set on which calculations in this paper are based is given in Section $\mathrm{C}$ of the Additional file 1.

Possible Other Approaches. Considering the uncertainties in both Methods I and II, it is prudent to search for additional phenomena that might be used to check $a_{S} 0$ values. The $\mathrm{a}_{S} \mathrm{O}$-sensitivity of greigite solubility offers one possibility. Fe(III)-bearing particles that settle into sulfidic waters release dissolved Fe(II) owing to reductive dissolution. Consequently dissolved Fe(II) concentrations usually increase with water depth until saturation with respect to an Fe-sulfide phase is reached. Below the depth of saturation, Fe(II) usually declines as sulfide continues to rise. Thus in euxinic (sulfidic) waters (i.e. $\left.\Sigma \mathrm{S}^{-\mathrm{II}}>\Sigma \mathrm{Fe}^{\mathrm{II}}\right)$ the horizon where saturation is reached can be recognized by a maximum in the dissolved $\mathrm{Fe}^{\mathrm{II}}$ concentration profile [56]. (In ferruginous waters, where $\Sigma \mathrm{Fe}^{\mathrm{II}}>\Sigma \mathrm{S}^{-\mathrm{II}}$, sulfide reaches a peak at the saturation horizon instead of Fe.) Mackinawite (tetragonal FeS) is believed to be the first iron sulfide to precipitate in sulfidic waters [57], but if ambient $\mathrm{a}_{\mathrm{S}} 0$ in the saturation zone is high enough, mackinawite can transform to greigite (cubic $\mathrm{Fe}_{3} \mathrm{~S}_{4}$ ).

For example, the $\mathrm{Fe}^{\mathrm{II}}$ concentration maximum in the Black Sea occurs at $180 \mathrm{~m}$ [58]. At this horizon the activity product, $\mathrm{Q}_{\mathrm{FeS}}=\mathrm{a}_{\mathrm{Fe} 2+} \mathrm{a}_{\mathrm{H} 2 \mathrm{~S}} / 10^{-2 \mathrm{pH}}$, approaches the solubility product constant for mackinawite and remains nearly constant at greater depth even though dissolved 
Fe declines [58]. Selective leaching experiments show that the acid-volatile sulfide particles in the deep waters behave analytically as if mostly $\mathrm{FeS}$, with only minor amounts of $\mathrm{Fe}_{3} \mathrm{~S}_{4}$ [59]. In contrast, the deep waters of Framvaren Fjord and the Cariaco Basin contain mainly $\mathrm{Fe}_{3} \mathrm{~S}_{4}$-like acid-volatile sulfide particles, according to selective leaching tests, and contain only minor or negligible FeS $[59,60]$. In agreement, aqueous activity products $\left(\mathrm{Q}_{\mathrm{FeS}}\right)$ suggest equilibrium with a phase that is distinctly less soluble than mackinawite [60,61]. These examples imply that even though greigite is a transient in pyrite formation [62], it nevertheless can accumulate and acquire sufficient reactive surface area in some euxinic waters to control dissolved Fe solubility.

Greigite's solubility can be described by reaction 14 :

$$
\begin{aligned}
& 1 / 3 \mathrm{Fe}_{3} \mathrm{~S}_{4}(\text { greig })+2 \mathrm{H}^{+} \leftrightarrow \mathrm{Fe}^{2+}+\mathrm{H}_{2} \mathrm{~S}(\mathrm{aq})+1 / 3 \mathrm{~S}^{0} \\
& K_{\text {greig }}=\frac{a_{\mathrm{Fe}^{2+}} a_{\mathrm{H}_{2} \mathrm{~S}}}{10^{-2 p H}} a_{S^{o}}^{1 / 3}=Q_{\mathrm{FeS}} a_{S^{o}}^{1 / 3}
\end{aligned}
$$

Therefore in waters equilibrated with greigite,

$$
a_{S^{0}}=\left(\frac{K_{\text {greig }}}{Q_{F e S}}\right)^{3}
$$

Unfortunately, the cubic exponent in this equation causes $a_{S} 0$ to be very sensitive to analytical uncertainty in $\mathrm{Q}_{\mathrm{FeS}}$. Additionally, the value of $\mathrm{K}_{\text {greig }}$ is poorly known. The only previous estimate gave $\log \mathrm{K}_{\text {greig }} \approx 2.6$ based on the supposition that $a_{S} 0=1.0$ in the solutions under study [63]. It has been suggested that this $K_{\text {greig }}$ is too large because the material studied may have contained mackinawite impurities [64]. Aside from these problems, not all sulfidic waters come to equilibrium with greigite.

It must be kept in mind that mere presence of greigite does not prove equilibrium. Intracellular greigite is purposefully synthesized and used by magnetotactic bacteria [65], which seem able to do this even when surrounding waters are undersaturated with this mineral. In the Cariaco Basin, sub-nanomolar concentrations of particulate greigite are detected at depths as shallow as $30 \mathrm{~m}$ (Supplemental Material for [60]), even though free sulfide is not detected until about $260 \mathrm{~m}$ and even though the dissolved $\mathrm{Fe}^{\mathrm{II}}$ maximum that probably signals true saturation with an Fe sulfide mineral is found at $400 \mathrm{~m}$. At $400 \mathrm{~m}$ and below, $\log \mathrm{Q}_{\mathrm{FeS}}$ is reasonably constant, as would be expected in greigite-saturated waters of roughly constant as 0 .

From published and archived data on the Cariaco Basin $[60,66], a_{S} 0$ can be estimated by Method II from the chemocline at $260 \mathrm{~m}$ to $400 \mathrm{~m}$ (taking dissolved $\Sigma \mathrm{S}^{0}$ to be the difference between reported total $\mathrm{S}^{0}$ and particulate $S^{0}$ values). Unfortunately $S^{0}$ data are not available below $400 \mathrm{~m}$. However, at $400 \mathrm{~m}$ and below, where greigite saturation is inferred, $\mathrm{a}_{\mathrm{S}} 0$ can be estimated by equation 15 . Figure 5 shows a spliced $a_{s} 0$ profile for the Cariaco Basin. To obtain agreement at $400 \mathrm{~m}$, it was necessary to adjust $\log \mathrm{K}_{\text {greig }}$ to 2.24 , a reasonable value but slightly lower than Berner's value of 2.6 [63]. The figure shows that as 0 reaches the limit of colloidal $\mathrm{S}^{0}$ saturation in the suboxic zone where sulfide oxidation processes are rapid [66]. Below the suboxic zone $\mathrm{a}_{\mathrm{S}} 0$ declines to values on the order of 0.5 .

Potentiometry offers another possible approach to checking a $\mathrm{O}$ values. Measurement of Eh (i.e. Pt electrode potential referenced to the standard $\mathrm{H}_{2}$ electrode) has fallen out of favor in recent decades because in oxic natural waters irreversible, mixed potentials are obtained, and these are not interpretable with thermodynamics [14,67]. Nonetheless, early workers demonstrated that reversible potentials are established at inert Pt electrodes in sulfidepolysulfide solutions [68] as well as in sulfidic natural waters $[69,70]$. A Nernst equation describing this process can be formulated as follows, where $\mathrm{Eh}^{0}=-0.0626 \mathrm{~V}$ is calculated from thermodynamic tables [71]:

$$
\text { Eh(volts })=-0.0626+\frac{2.3 R T}{2 F} \log \left(\frac{10^{-p H}}{a_{H S-}}\right)+\frac{2.3 R T}{2 F} \log \left(a_{S^{0}}\right)
$$

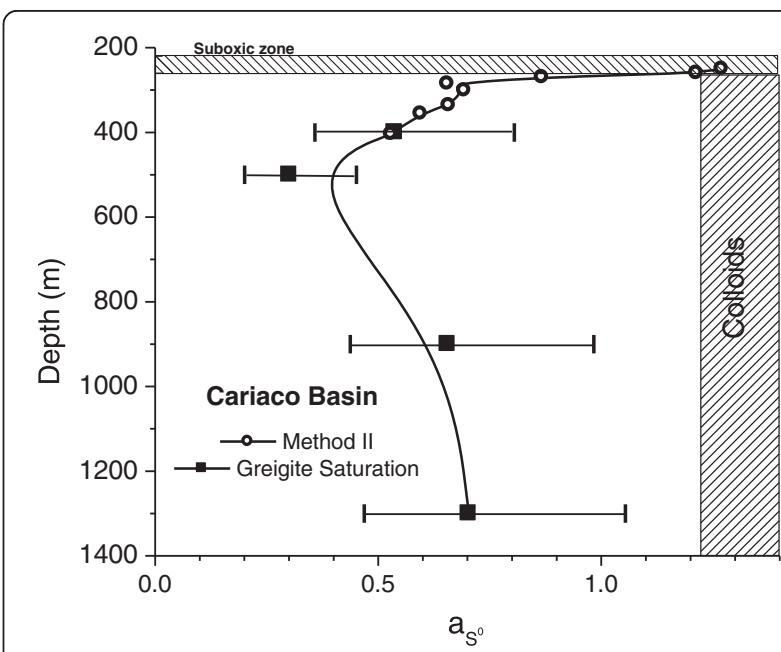

Figure 5 Activity of zero-valent sulfur vs. depth in the Cariaco Basin. From 250 to $400 \mathrm{~m}$, as 0 was calculated by Method II using data from an April 2007 cruise [66]; salinity $=36.3$ and $T=17.5^{\circ} \mathrm{C}$ Assuming $\pm 5 \%$ uncertainty in $\Sigma \mathrm{S}^{0}$ and $\Sigma \mathrm{S}^{-11}$ measurements and a pH uncertainty of \pm 0.02 , error bars for Method II would fall within the area of the symbols. At $400 \mathrm{~m}$ and deeper, as 0 was calculated from greigite solubility using data from a May 2008 cruise [60]; error bars depict only measurement uncertainty and are based on an assumption that $\Sigma \mathrm{Fe}^{\|}$and $\Sigma \mathrm{S}^{-11}$ are measured to $\pm 5 \%$ precision and $\mathrm{pH}$ to \pm 0.02 . $\log \mathrm{K}_{\text {greig }}=2.24$ was chosen to make the two methods agree at $400 \mathrm{~m}$. 
In more than fifty cores from tidal flats and bogs, Berner [69] measured $\mathrm{Eh}$ and $\mathrm{E}_{\mathrm{Ag} 2 \mathrm{~S}}$, the potential of an $\mathrm{Ag} / \mathrm{Ag}_{2} \mathrm{~S}$ electrode, which can be described by:

$$
E_{A g_{2} S}(\text { volts })=-0.267+\frac{2.3 R T}{2 F} \log \left(\frac{10^{-p H}}{a_{H S-}}\right)
$$

Combining equations 16 and 17 gives:

$$
E h-E_{A g_{2} S}=+0.204+\frac{2.3 R T}{2 F} \log \left(a_{S^{0}}\right)
$$

Thus if $\mathrm{a}_{\mathrm{S}} \mathrm{O}=1.0$, then $\left(\mathrm{Eh}-\mathrm{E}_{\mathrm{Ag} 2 \mathrm{~S}}\right)$ would be +0.204 . Over a wide range in both $\mathrm{Eh}$ and $\mathrm{E}_{\mathrm{Ag} 2 \mathrm{~S}}$, Berner observed $\left(E h-E_{\mathrm{Ag} 2 \mathrm{~S}}\right)$ values falling within a $\sim 0.05 \mathrm{~V}$-wide band that was consistent with $\mathrm{a}_{\mathrm{S}} \mathrm{O}$ values within an order of magnitude of unity; most samples were characterized by $\mathrm{a}_{\mathrm{S}} 0<1$.

In experienced hands, Pt electrode potentials can produce as 0 values consistent with Method II. For example, the data of Boulègue et al. [72] from the $\mathrm{pH} 6.9$ spring $\mathrm{K} 22$ at Puzzichello, in Corsica, yield $\mathrm{a}_{\mathrm{S}} \mathrm{O}=1.57$ and $\mathrm{a}_{\mathrm{HS}-}=$ $0.00063 \mathrm{M}$ by Method II. From equation 16, this is consistent with $\mathrm{Eh}=-0.161 \mathrm{~V}$, which compares well with the measured Eh of $-0.155 \pm 0.010 \mathrm{~V}$. The small colloidal $\mathrm{S}^{0}$ supersaturation indicated by $a_{S} 0>1.22$ probably represents a perturbation induced as the water emerged from the subsurface [72].

However, in other cases Eh calculated from equation 16 is inconsistent with measured Eh for reasons still unknown. The inconsistencies might point to fatal obstacles associated with attempting Eh measurements in sulfidic natural waters. Alternatively, they might simply testify to imperfections in the available data (for example, Boulègue and Michard [70] note that at near-neutral $\mathrm{pH}$ it is usually necessary to equilibrate Pt electrodes for several hours to get reproducible readings-something that is hardly ever done in the field). In the lefthand panel of Figure 6, a 0 has been estimated by Method II in the Black Sea, and in the righthand panel, Eh values implied by the $a_{s} 0$ values are crosschecked against some old Eh measurements. Qualitatively the Eh profiles show similarities, but quantitatively, agreement is poor. Unfortunately, some of this poor agreement might be due to temporal changes in the Black Sea, because the datasets being compared were not obtained contemporaneously.

A key limitation of Eh measurements is their inherent imprecision; a typical measurement uncertainty of $\pm 0.01 \mathrm{~V}$ corresponds to a factor of two uncertainty in $a_{S} 0$. Nevertheless, Eh is extremely attractive as a possible screening method for $a_{S} 0$ in natural waters because it can quite easily be deployed in situ, avoiding risks of oxidation, $\mathrm{H}_{2} \mathrm{~S}(\mathrm{~g})$ loss, $\mathrm{S}_{8}$ sorption and $\mathrm{pH}$ shifts that can occur when samples must be withdrawn from sulfidic environments for analysis. Additionally, because $\mathrm{Eh}$ is in principle a

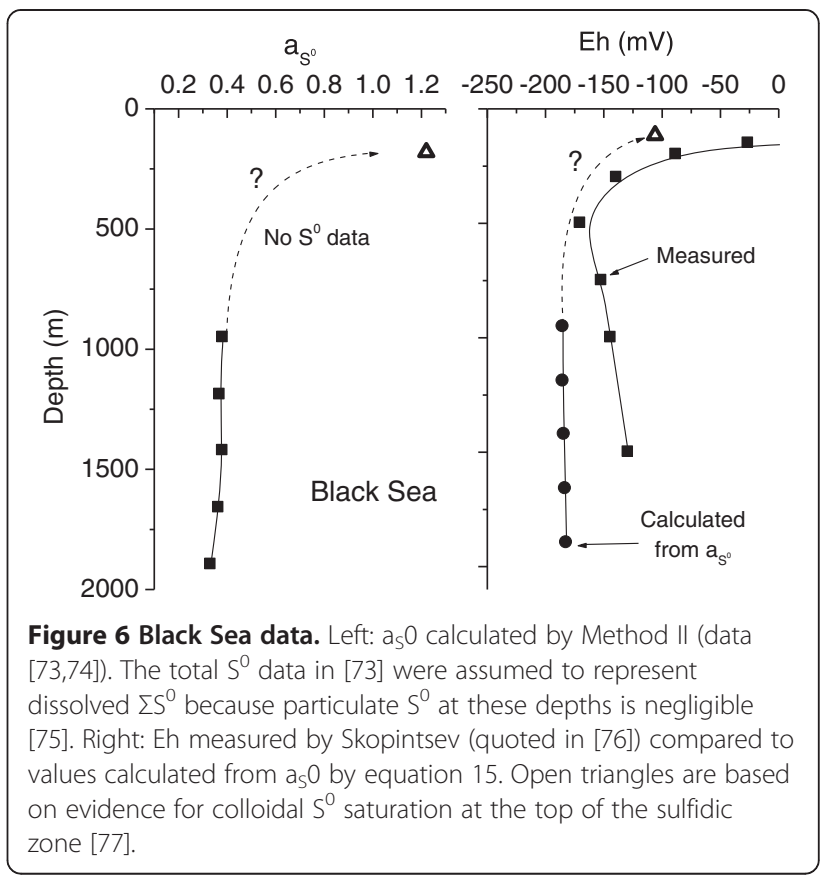

thermodynamic property, it should be unaffected by $S^{0}$ colloids. Because of these attractive characteristics, further research on this approach might be warranted.

\section{Discussion}

Range of $a_{S} 0$ in Natural Waters. In addition to the $a_{S} 0$ profiles in Figures 5 and 6, a few isolated examples of $\mathrm{a}_{\mathrm{S}} 0$ values are presented in Table 1 in order to illustrate the range observed in nature. These values were all calculated by Method II. The first two entries in the table, Enghien-les-Bains and Puzzichello springs, are found to have quite high $a_{S} 0$, probably artifacts due to inclusion of colloidal $S^{0}$ in the $\Sigma S^{0}$ measurements. Independent evidence for colloids was indeed observed at those sites and attributed to oxidation of sulfide as the deep ground waters mixed with shallow, oxygenated ground waters prior to their emergence in the springs. Lower Mystic Lake deep water as well as pore water from immediately below the sediment-water interface in Lake Croche also have calculated $a_{S} 0$ above the colloidal $S^{0}$ limit, hinting at the presence of colloids. Even though the Lake Croche samples were collected by a sophisticated dialysis method that should have excluded colloids exceeding $0.2 \mu \mathrm{m}$ diameter, their low $\mathrm{pH}$ may have promoted postsampling $\mathrm{H}_{2} \mathrm{~S}(\mathrm{~g})$ loss through the dialysis membranes (most polymers are extremely permeable to $\mathrm{H}_{2} \mathrm{~S}$ gas). Such loss would cause a transient $\mathrm{a}_{\mathrm{S}} \mathrm{0}$ spike and possibly initiate colloid precipitation. Two pore water samples from Great Marsh, a tidal salt marsh subject to intermittent exposure to air, cluster near saturation with respect to colloidal and rhombic S. Although not shown, similar values can be obtained from an independent dataset 
Table 1 Method II applied to selected natural waters

\begin{tabular}{|c|c|c|c|c|c|c|c|c|}
\hline Sample & Ref. & $\Sigma \mathrm{S}^{-11}(\mathrm{mM})$ & $\Sigma \mathrm{S}^{0}(\mathrm{mM})$ & I (mM) & $\mathrm{T}\left({ }^{\circ} \mathrm{C}\right)$ & $\mathrm{pH}$ & $\mathrm{HS}^{-}(\mathrm{mM})$ & $\mathrm{a}_{\mathrm{s}} \mathrm{O}$ \\
\hline Enghien-les-Bains, ER2 & [79] & 1.13 & 1.65 & 10 & 14 & 7.42 & 0.53 & 2.14 \\
\hline Puzzichello K22 & [72] & 1.64 & 0.165 & 21 & 14.5 & 6.9 & 0.633 & 1.57 \\
\hline Lower Mystic Lake (Ave of deep water) & [32] & 7.1 & 0.33 & 400 & 8 & 6.80 & 2.30 & 1.37 \\
\hline Lake Croche $+3.5 \mathrm{~cm}^{\dagger}$ above sed. surface & [80] & 0.0081 & 0.0010 & $10^{*}$ & $5^{*}$ & 5.67 & 0.00019 & 1.42 \\
\hline Lake Croche $-0.5 \mathrm{~cm}^{\dagger}$ below sed. surface & {$[80]$} & 0.011 & 0.0045 & $10^{*}$ & $5^{*}$ & 5.96 & 0.00050 & 1.71 \\
\hline Lake Croche $-3.5 \mathrm{~cm}^{\dagger}$ below sed. surface & {$[80]$} & 0.0037 & 0.0007 & $10^{*}$ & $5^{*}$ & 6.05 & 0.00020 & 1.36 \\
\hline Great Marsh SU-82, 10-14 cm below sed. surface & [81] & 2.15 & 0.22 & 1170 & $15^{*}$ & 7.02 & 1.08 & 1.26 \\
\hline Great Marsh SU-82, 50-54 cm below sed. surface & [81] & 5.46 & 0.33 & 810 & $15^{*}$ & 7.17 & 3.26 & 0.98 \\
\hline Prairie Pot Hole P1 pore water; April & [36] & 2.37 & 0.079 & 480 & $15^{*}$ & 8.62 & 2.29 & 0.30 \\
\hline Prairie Pot Hole P1 pore water; Sept & [36] & 1.95 & 0.079 & 480 & $15^{*}$ & 7.36 & 1.36 & 0.77 \\
\hline Mahoney Lake deepest water column, 14 m & {$[82,83]$} & 27 & 0.29 & 600 & 14 & 7.30 & 18.0 & 0.58 \\
\hline
\end{tabular}

*When I or $\mathrm{T}$ were not reported, estimated values were used. ${ }^{\dagger} \mathrm{DOC}=10 \mathrm{mg} / \mathrm{L}$ assumed.

acquired at this same marsh [78]. On the other hand, pore waters from a Prairie Pothole lake, and bottom waters from Mahoney Lake are appreciably undersaturated with respect to both colloidal and rhombic sulfur and are seen to have $a_{S} 0$ in the range of deep euxinic basin waters (Figures 5 and 6).

In Lake Croche's low-pH, low-sulfide waters, $\mathrm{S}_{8}$ is determined to be the major carrier of $\Sigma S^{0}$, and in the presence of $\geq 5 \mathrm{mg} / \mathrm{L}$ DOC, most $\mathrm{S}_{8}$ will be associated with organic macromolecules. As a result, Croche's calculated $a_{S} 0$ values are sensitive to DOC concentration. At the opposite extreme, because of Mahoney Lake's much higher $\mathrm{pH}$ and sulfide concentrations, $\mathrm{S}_{8}$ is negligible relative to polysulfides, and its as 0 is consequently insensitive to DOC concentration even though Mahoney's DOC is extraordinarily high ( 800 $\mathrm{mg} / \mathrm{L}$ [82]).

From the derived $\mathrm{a}_{\mathrm{S}} \mathrm{O}$ and $\left[\mathrm{HS}^{-}\right]$values in Table 1 , the concentrations of $S_{8}$ and all polysulfide ions can be calculated easily from equilibrium constants (values compiled in the Additional file 1). Perhaps surprisingly, the concentrations of polysulfide ions are found not to be simply proportional to $\mathrm{a}_{\mathrm{S}} 0$ or to $\Sigma S^{0}$. For example, in Lake Croche the calculated concentrations of polysulfides are all $<0.002 \mu \mathrm{M}$; in contrast, in Mahoney Lake concentrations of $\mathrm{S}_{4}{ }^{2-}$ and $\mathrm{S}_{5}{ }^{2-}$ each exceed $20 \mu \mathrm{M}$. (The deep waters of Mahoney, and also Lower Mystic, are reported to have a marked yellow color, probably due to polysulfides.) The immense difference implies that a kinetic process dependent on polysulfide concentration, such as degradation of a pesticide [33-35], would be $>10^{4}$ faster at the sediment-water interface in Mahoney than in Croche. A rate disparity this large would not be anticipated simply by inspection of either the $a_{S} 0$ or $\Sigma S^{0}$ values in Table 1.

Notice further in Table 1 the non-intuitive relationship between the concentration and the activity of zerovalent sulfur, $\Sigma S^{0}$ and $a_{S} 0$. For example, high values of
$\mathrm{a}_{\mathrm{S}} 0$ in Lake Croche are associated with very low $\Sigma \mathrm{S}^{0}$ concentrations, whereas low as 0 values in Mahoney Lake are associated with very high $\Sigma S^{0}$ concentrations; direct proportionality between as 0 and $\Sigma S^{0}$ does not occur. This behavior arises because the analytically measurable quantity, $\Sigma \mathrm{S}^{0}$, is not the concentration of a single chemical species. Rather, it is the concentration of an array of labile species that vary relative to one another depending on solution composition.

Kamyshny and coworkers, using an approach related to Method I, found $a_{S} 0$ (which they designated the relative saturation level, RSL) of 0.61 to 0.77 in sulfidic well waters [52]. In Wadden Sea tide pools [45], as 0 values were in the range 0.3 to 0.9 . Curiously, these latter samples contained visual evidence of sulfur colloids even though $\mathrm{a}_{\mathrm{S}} 0<<1.22$. One possible explanation is that the colloids were composed of biogenic sulfur, a hydrophilic substance which is less soluble than both inorganic colloidal sulfur and rhombic sulfur. Biogenic sulfur particles produced by sulfide-oxidizing Thiobacilli are characterized by $a_{S} 0=0.95 \pm 0.02$ at $21^{\circ} \mathrm{C}$ according to data of Kleinjan et al. [46] as analyzed by equations 5 and 6 . Probably these microbes enhance their energy harvest from sulfide oxidation by discharging a metabolic $\mathrm{S}^{0}$ product, possibly a long-chain polythionate [47], in which $\mathrm{a}_{\mathrm{S}} \mathrm{O}$ is lower than in colloidal or rhombic sulfur.

Production and Decomposition of $S^{O}$. Dissolved zerovalent sulfur is metastable. Given sufficient time, it would spontaneously disproportionate to sulfide and sulfate:

$$
\mathrm{S}^{0}+\mathrm{H}_{2} \mathrm{O} \rightarrow 0.75 \mathrm{H}_{2} \mathrm{~S}+0.25 \mathrm{SO}_{4}{ }^{2-}+0.5 \mathrm{H}^{+}
$$

Abiotically, this reaction is extremely sluggish under conditions near Earth's surface (half-life of centuries [29]). However microorganisms are known to catalyze it at high $\mathrm{a}_{\mathrm{S}} \mathrm{O}$, high $\mathrm{pH}$ and low $\mathrm{a}_{\mathrm{H} 2 \mathrm{~S}}$, recovering some of the trapped free energy $[84,85]$. For the samples discussed in 
this paper, the available free energy is shown in Figure 7 based on the derived $a_{S} 0$ values. Figure 7 shows that disproportionation of $S^{0}$ is uniformly exergonic in these samples, but only slightly so in the extreme case of Mahoney Lake.

Disproportionation is only one path by which $S^{0}$ can be consumed in anoxic environments. Abiotically, $\mathrm{S}^{0}$ can be scavenged by pyrite formation [62] and by forming covalently bonded organic sulfur compounds [86]. Owing to their high as 0 (Figure 5 and 6), chemoclines manufacture much of the framboidal pyrite found in euxinic basin sediments [62]. Microorganisms also can reduce $\mathrm{S}^{0}$ in reactions with hydrogen, methane and other organic compounds [4]. Except near redox interfaces, lack of oxidizing agents curtails oxidative pathways of $\mathrm{S}^{0}$ consumption.

In sulfidic waters these loss processes are opposed by production processes mainly involving both biotic and abiotic oxidation of sulfide by various oxidizing agents $\left(\mathrm{Fe}{ }^{\mathrm{III}}, \mathrm{Mn}^{\mathrm{III}, \mathrm{IV}}, \mathrm{NO}_{3}{ }^{-}, \mathrm{NO}_{2}{ }^{-}\right.$and of course $\mathrm{O}_{2}$ ) [4,60]. As Figures 5 and 6 suggest, these production processes are most active near redox interfaces where concentration profiles of oxidizing agents and sulfide overlap to a limited extent. If sulfidic waters occur at depths shallow enough to be in the euphotic zone, anoxygenic photosynthesis becomes a very important source of $\mathrm{S}^{0}$. In

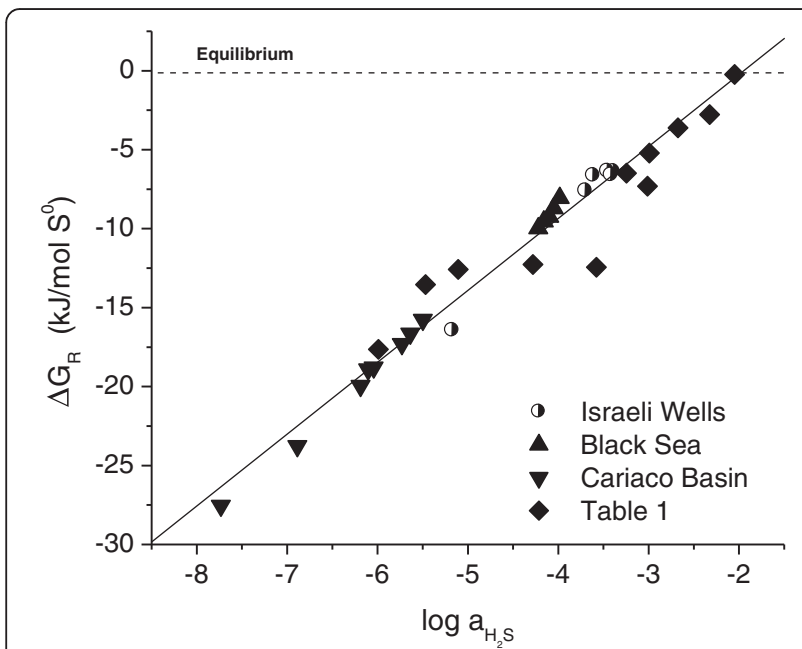

Figure 7 Free energy available per mole $S^{0}$ by disproportionation of $\mathbf{S}^{0}$ to sulfide and sulfate. Based on data in Figures 5 and 6 and in Table 1 as well as [52]. $\Delta G_{R}$ has been plotted against $\log \left(a_{\mathrm{H} 2 \mathrm{~S}}\right)$ because most of the $\Delta G_{R}$ variation in this dataset is due to variation in $\mathrm{H}_{2} \mathrm{~S}$. Zero-valent sulfur is shown to be thermodynamically unstable in all the samples; that is, disproportionation would produce a decrease in free energy. The sample at upper right, lying very close to the equilibrium line, is the extremely sulfidic Mahoney Lake sample. It should be noted that $\Delta G_{R}$ values depend on how reaction 19 is written; some previous workers [84] write the reaction to produce one mole of $\mathrm{SO}_{4}{ }^{2-}$, rather than $1 / 4$ mole, and consequently obtain $\Delta G_{R}$ values four times larger. This arbitrary choice affects the values on the vertical scale but not the pattern of the data. For reaction $19, \Delta G_{R}{ }^{0}=+30.124 \mathrm{~kJ} / \mathrm{mol}$ [71]. deeper waters of euxinic basins, sinking particles may be the principal $\Sigma \mathrm{S}^{0}$ source. Detrital $\mathrm{Fe}^{\mathrm{III}}$-bearing particles that are too refractory to react quickly with sulfide as they fall through the chemocline will be one source [87]. Particles may also carry $\mathrm{S}^{0}$, itself. Particle-borne $\mathrm{S}^{0}$ would include intracellular $S^{0}$, flocs formed when hydrophobic $\mathrm{S}^{0}$ colloids coagulate with detrital and biogenic particles and $S^{0}$ sorbed to such particles. Often, $S^{0}$ from these sources accumulates in elemental form in sediments beneath sulfidic waters $[88,89]$.

Figure 5 indicates how these opposing processes play out in the Cariaco Basin. In the suboxic zone, owing to very rapid production of $S^{0}$, the calculated as 0 reaches the limit imposed by rapid colloid precipitation; $\mathrm{S}^{0}$ accumulates in both particulate and dissolved forms [66]. With increasing depth, as 0 declines, partly due to much lower production rates in the absence of oxidants and partly due to biological reduction. Sulfur isotope data, which arguably could imply active disproportionation in Cariaco's deeper waters, are better explained by very slow sulfate reduction rates [90]. Figure 6 suggests that similar processes occur in the Black Sea, but the data are incomplete.

In passing, it should be noted that published polysulfide ion concentrations in the deep Cariaco Basin were calculated in ref [66] on the basis of the common assumption that $\mathrm{a}_{\mathrm{S}} \mathrm{O}=1.0$. At $400 \mathrm{~m}$ in the Cariaco Basin, the calculated $\mathrm{S}_{5}{ }^{2-}$ concentration was $0.53 \mu \mathrm{M}$ under this assumption. Here, where $a_{S} 0$ is evaluated by Method II, $\mathrm{S}_{5}{ }^{2-}$ is calculated to be an order of magnitude less, $0.046 \mu \mathrm{M}$. This survey provides no evidence that natural waters tend to be buffered near $\mathrm{a}_{\mathrm{S}} 0=1.0$. Enormous errors can be introduced by making this seemingly innocuous assumption, and such errors can mislead assessments of polysulfides' role in such processes as discussed below.

Broader Geochemical Implications. Having for the first time estimates of the range of $\mathrm{a}_{\mathrm{S}}{ }^{0}$ values in a variety of sulfidic waters, it is of interest to consider what these values imply about the geochemistry of elements other than sulfur. Here the effects of $\mathrm{a}_{\mathrm{S}}{ }^{0}$ on trace element speciation and sulfide mineral stability are briefly discussed.

Both sulfide and polysulfide ligands compete for $\mathrm{Hg}^{2+}$ in reduced natural waters. At near neutral $\mathrm{pH}$ and $\Sigma \mathrm{S}^{-\mathrm{II}}>$ $0.1 \mathrm{mM}$, either $\mathrm{HgS}_{2}{ }^{2-}$ or $\mathrm{Hg}\left(\mathrm{S}_{\mathrm{n}}\right)_{2}{ }^{2-}$ can predominate, depending on $\mathrm{a}_{S} \mathrm{O}[26]$ :

$$
2(\mathrm{n}-1) \mathrm{S}^{0}+\mathrm{HgS}_{2}{ }^{2-} \leftrightarrow \mathrm{Hg}\left(\mathrm{S}_{\mathrm{n}}\right)_{2}{ }^{2-} \quad \mathrm{K}=10^{1.3}
$$

The value of $n$, the number of sulfur atoms in the polysulfide ligands, has not been determined but is likely to be either 4 or 5 . From published stability constants [26], the polysulfide complex is predicted to predominate 
at $\mathrm{as}_{\mathrm{S}}^{0}>0.6$ to 0.7 for $\mathrm{n}=4$ or 5 . Thus the as 0 boundary separating predominance of the sulfide from the polysulfide complexes at neutral $\mathrm{pH}$ falls in the range of $\mathrm{a}_{\mathrm{S}} 0$ values found in natural waters. The $\mathrm{Hg}\left(\mathrm{S}_{\mathrm{n}}\right)_{2}{ }^{2-} / \mathrm{HgS}_{2}{ }^{2-}$ ratio will increase steeply in proportion to as $\mathrm{O}$. Microbial $\mathrm{Hg}$ methylation, which is the entry point of $\mathrm{Hg}$ into aquatic food chains, is known to be sensitive to $\mathrm{Hg}$ speciation, with the polysulfide complex apparently not available for methylation [28,91].

In contrast, the analogous boundary separating predominance of $\mathrm{Ag}(\mathrm{HS})_{2}{ }^{-}$from $\mathrm{Ag}\left(\mathrm{S}_{4}\right)_{2}{ }^{3-}$ lies at $\mathrm{a}_{\mathrm{S}}{ }^{0}=2.14$ at $\mathrm{pH} 7$ but falls to 0.96 at $\mathrm{pH} 8$ (data from [23,92]). Thus $\operatorname{Ag}\left(\mathrm{S}_{4}\right)_{2}{ }^{3-}$ is relatively less stable than $\mathrm{Hg}\left(\mathrm{S}_{\mathrm{n}}\right)_{2}{ }^{2-}$ and likely to be important only at higher $\mathrm{pH}$ in the range of $a_{S} 0$ found at earth-surface temperatures in nature.

Similar calculations indicate that $\mathrm{Sb}^{\mathrm{V}}$ thioanions will predominate over $\mathrm{Sb}^{\mathrm{III}}$ thioanions [19], and $\mathrm{As}^{\mathrm{V}}$ thioanions will predominate over $\mathrm{As}^{\mathrm{III}}$ thioanions at as 0 values found in Table 1 and Figures 5 and 6 [21]. Although in both cases improvements are needed in the thermodynamic data, these predictions of the importance of oxidized thioanions in reducing natural waters seem to be borne out qualitatively by field measurements [93-96].

Reaction of $\mathrm{S}^{0}$ with $\mathrm{MoOS}_{3}{ }^{2-}$ in sulfidic solution produces an unstable $\mathrm{Mo}(\mathrm{VI})$ intermediate, $\operatorname{MoOS}\left(\mathrm{S}_{2}\right)_{2}{ }^{2-}$, that undergoes spontaneous rearrangement to a Mo(IV) complex [20]. This may be the initiation step in the scavenging of Mo from sulfidic natural waters and might explain the reduced oxidation state of Mo in sediments [97]. From data in [20], the $\mathrm{MoOS}\left(\mathrm{S}_{2}\right)_{2}{ }^{2-} / \mathrm{MoOS}_{3}{ }^{2-}$ ratio would reach 0.1 at an $a_{s} 0$ value in the neighborhood of 0.5 , a threshold exceeded in most of the sulfidic waters surveyed in this paper.

The $a_{s} 0$ values in Figures 5 and 6 and in Table 1 are quite high compared to equilibrium phase boundaries in several common mineral systems. The transformation of mackinawite to greigite,

$$
3 \mathrm{FeS}+\mathrm{S}^{0} \rightarrow \mathrm{Fe}_{3} \mathrm{~S}_{4},
$$

occurs at $\mathrm{a}_{\mathrm{S}} 0>10^{-2.91}$ (taking $\log \mathrm{K}_{\text {greig }}$ to be 2.24 from this work and $\log K_{\text {mack }}$ to be 3.21 [98]). Realgar becomes unstable relative to orpiment at $\mathrm{a}_{\mathrm{S}} 0>10^{-3.91}$ [21]. Chalcocite, djurleite and anilite all become unstable relative to covellite at $a_{S} 0>10^{-2.29}$ [25]. Thus the as 0 values in Figures 5 and 6 and Table 1 all imply that in each of these three mineral systems the most sulfur-rich mineral (greigite, orpiment, covellite)) would be the stable sulfide mineral.

\section{Conclusions}

The activity of zero-valent sulfur is an important property of sulfidic waters, but one that cannot be measured directly. Methods for determining it from measurable properties of natural waters have been reviewed here. A critical test of the two principal methods against one another yields inconsistent results when $\Sigma \mathrm{S}^{0} / \Sigma \mathrm{S}^{-\mathrm{II}}$ is low. The source of this problem appears to lie in the thermodynamic data, especially for disulfides. The inconsistencies largely can be removed by a pragmatic modification to accepted ionization constants for polysulfides, but this approach requires further investigation. A survey of $a_{5} 0$ in sulfidic natural waters yields values in the 0.3 to $>1.2$ range. Those values $>1.2$ are believed to be artifacts caused by inclusion of colloidal sulfur in $\Sigma \mathrm{S}^{0}$ determinations. In all of the surveyed environments, $S^{0}$ is unstable with respect to $\mathrm{SO}_{4}{ }^{2-}$ and sulfide. In these environments, as 0 values are high enough to have a significant influence on the biogeochemical behavior of $\mathrm{Cu}, \mathrm{Hg}$, As, $\mathrm{Sb}, \mathrm{Mo}$ and probably many other trace elements.

\section{Additional file}

Additional file 1: With this paper is provided an additional file that consists of six parts. A) Some additional details clarifying why equilibrium thermodynamic models are appropriate for describing zero-valent sulfur chemistry. B) Details concerning derivation of the equations associated with Method II. C) Thermodynamic data used in this paper. D) Full-page versions of Figures 1 to 3. E) Numerical tables relevant to the comparison of Methods I and II against one another. F) Tables illustrating propagation of analytical errors.

\section{Competing interests}

The author declares that he has no competing interests.

\section{Acknowledgement}

The author is pleased to acknowledge the help of Andre Tessier and Feiyue Wang who checked some of the calculations and provided a review of the manuscript. Three anonymous reviewers also are thanked for their suggestions for improving the manuscript.

Received: 3 April 2014 Accepted: 29 July 2014

Published: 19 August 2014

\section{References}

1. Jørgensen BB: Ecology Of The Sulphur Cycle: Oxidative Pathways In Sediments. In The Nitrogen and Sulphur Cycles. Edited by Cole JA, Ferguson SJ. New York: Cambridge University Press; 1988:32-63.

2. Williamson MA, Rimstidt JD: Correlation between structure and thermodynamic properties of aqueous sulfur species. Geochim Cosmochim Acta 1992, 56:3867-3880.

3. Suzuki I: Oxidation of inorganic sulfur compounds: chemical and enzymatic reactions. Can J Microbiol 1998, 45:97-105.

4. Ehrlich HL: Geomicrobiology Of Sulfur. In Geomicrobiology. 4th edition. Edited by Erhlich HL. New York: Marcel Dekker; 2002:18.

5. MacCrehan W, Shea D, Vairavamurthy MA, Schoonen MAA, Eglinton TI, Luther GW III, Manowitz B: Temporal Relationship Of Thiols To Inorganic Sulfur Compounds In Anoxic Chesapeake Bay Sediment Porewater. In Geochemical Transformations of Sedimentary Sulfur. Washington DC, USA: American Chemical Society Symposium Series 612; 1995.

6. Zopfi J, Ferdelman TG, Fossing H: Distribution and fate of sulfur intermediates-sulfite, tetrathionate, thiosulfate and elemental sulfurin marine sediments. Geological Society of American Special Paper 2004, 379:97-116.

7. Kamyshny A Jr, Borkenstein CG, Ferdelman TG: Protocol for quantitative detection of elemental sulfur and polysulfide zero-valent sulfur 
distribution in natural aquatic samples. Geostandards Geoanal Res 2009, 33:415-435.

8. Kamyshny A Jr, Zerkle AL, Mansaray ZF, Ciglenečki I, Bura-Nakić E, Farquhar J, Ferdelman TG: Biogeochemical sulfur cycling in the water column of a shallow stratified sea-water lake: Speciation and quadruple sulfur isotope composition. Mar Chem 2011, 127:144-154.

9. Tebbe FN, Wasserman E, Peet WG, Vatvars A, Hayman AC: Composition of elemental sulfur in solution: Equilibrium of $\mathrm{S}_{6}, \mathrm{~S}_{7}$ and $\mathrm{S}_{8}$ at ambient temperatures. J Amer Chem Soc 1982, 104:4971-4972.

10. Bura-Nakić E, Helz GR, Ciglenečki I, Ćosović B: Reduced sulfur species in a stratified seawater lake (Rogoznica Lake, Croatia); seasonal variations and argument for organic carriers of reactive sulfur. Geochim Cosmochim Acta 2009, 73:3738-3751.

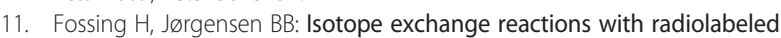
sulfur compounds in anoxic seawater. Biogeochem 1990, 9:223-245.

12. Kamyshny A Jr, Goifman A, Rizkov D, Lev O: Kinetics of disproportionation of inorganic polysulfides in undersaturated aqueous solutions at environmentally relevant conditions. Aquatic Geochem 2003, 9:291-304

13. Lindberg RD, Runnells DD: Ground water redox reactions: an analysis of equilibrium state applied to Eh measurements and geochemical modeling. Science 1984, 225:925-927.

14. Stefánsson A, Arnórsson S, Sveinbjörnsdótir AE: Redox reaction and potentials in natural water at disequilibrium. Chem Geol 2005 , 221:289-311.

15. Sack RO, Ebel DS: Thermochemistry Of Sulfide Mineral Solutions. In Reviews in Mineralogy and Geochemistry. Edited by Vaughan DJ. Chantilly VA: Geochemical Society and Mineralogical Society of America; 2006. 61:265-364.

16. Ryckelynck N, Stecher HA III, Reimers CE: Understanding the anodic mechanism of a seafloor fuel cell: interactions between geochemistry and microbial activity. Biogeochem 2005, 76:113-139.

17. Potter RW III, Barnes HL: Phase relations in the binary Hg-S. Amer Mineral 1978, 63:1143-1152.

18. Paquette $K E$, Helz GR: Inorganic speciation of mercury in sulfidic waters: the importance of zero-valent sulfur. Environ Sci Technol 1997, 31:2148-2153.

19. Helz GR, Valerio MS, Capps NE: Antimony speciation in alkaline sulfide solutions: role of zerovalent sulfur. Environ Sci Technol 2002, 36:943-948.

20. Vorlicek TP, Kahn MD, Kasuya Y, Helz GR: Capture of molybdenum in pyrite-forming sediments: role of ligand-induced reduction by polysulfides. Geochim Cosmochim Acta 2004, 68:547-556.

21. Helz GR, Tossell JA: Thermodynamic model for arsenic speciation in sulfidic waters: A novel use of $a b$ initio computations. Geochim Cosmochim Acta 2008, 72:4457-4468.

22. Couture R-M, Gobeil C, Tessier A: Arsenic, iron and sulfur co-diagenesis in lake sediments. Geochim Cosmochim Acta 2010, 74:1238-1255.

23. Cloke PL: The geologic role of polysulfides-Part II. The solubility of acanthite and covellite in sodium polysulfide solutions. Geochim Cosmochim Acta 1963, 27:1299-1319.

24. Berndt ME, Buttram T, Earley D III, Seyfried WE Jr: The stability of gold polysulfide complexes in aqueous sulfide solutions: 100 to $150^{\circ} \mathrm{C}$ and 100 bars. Geochim Cosmochim Acta 1994, 58:587-594.

25. Thompson RA, Helz GR: Copper speciation in sulfidic solutions at low sulfur activity: Further evidence for cluster complexes? Geochim Cosmochim Acta 1994, 58:2971-2983.

26. Jay JA, Morel FMM, Hemond HF: Mercury speciation in the presence of polysulfides. Environ Sci Technol 2000, 34:2196-2200.

27. Wang F, Tessier A: Zero-valent sulfur and metal speciation in sediment porewaters of freshwater lakes. Environ Sci Technol 2009, 43:7252-7257.

28. Kampalath RA, Lin C-C, Jay JA: Influences of zero-valent sulfur on mercury methylation in bacterial cultures. Water Air Soil Pollut 2013, 224:1399. doi:10.1007/s11270-012-1399-7.

29. Licht S, Davis J: Disproportionation of aqueous sulfur and sulfide: Kinetics of polysulfide decomposition. J Phys Chem B 1997, 101:2540-2545.

30. Barbash JE, Reinhard M: Reactivity Of Sulfur Nucleophiles Toward Halogenated Organic-Compounds In Natural Waters. In Biogenic Sulfur in the Environment. Edited by Saltzman ES, Cooper WJ. Washington DC, USA: American Chemical Society Symposium Series 393; 1989:101-138.

31. Roberts AL, Sanborn PN, Gschwend PM: Nucleophilic substitution reactions of dihalomethanes with hydrogen sulfide species. Environ Sci Technol 1992, 26:2263-2274.
32. Miller PL, Vasudevan D, Gschwend PM, Roberts AL: Transformation of hexachlorethane in a sulfidic natural waters. Environ Sci Technol 1998, 32:1269-1275

33. Lippa KA, Roberts AL: Nucleophilic aromatic substitution reaction of chloroazines with bisulfide $\left(\mathrm{HS}^{-}\right)$and polysulfides $\left(\mathrm{S}_{\mathrm{n}}{ }^{2-}\right)$. Environ Sci Technol 2002, 36:2008-2018.

34. Loch AR, Lippa KA, Carlson DL, Chin YP, Traina SJ, Roberts AL: Nucleophilic aliphatic substitution reactions of propachlor, alachlor, and metalachlor with bisulfide $\left(\mathrm{HS}^{-}\right)$and polysulfides $\left(\mathrm{S}_{\mathrm{n}}{ }^{2-}\right)$. Environ Sci Technol 2002, 36:4065-4073.

35. Wu T, Jans U: Nucleophilic substitution reactions of chlorpyifos-methyl with sulfur species. Environ Sci Technol 2006, 40:784-790.

36. Zeng T, Ziegelgruber KL, Chin Y-P, Arnold WA: Pesticide processing potential in prairie pothole porewaters. Environ Sci Technol 2011, 45:6814-6822

37. Zeng T, Chin Y-P, Arnold WA: Potential for abiotic reduction of pesticides in prairie pothole porewaters. Environ Sci Technol 2012, 46:3177-3187.

38. Shea D, Helz GR: The solubility of copper in sulfidic waters; sulfide and polysulfide complexes in equilibrium with covellite. Geochim Cosmochim Acta 1988, 52:1815-1825.

39. Kamyshny A Jr, Goifman A, Gun J, Rizkov D, Lev O: Equilibrium distribution of polysulfide ions in aqueous solutions at $25^{\circ} \mathrm{C}$ : A new approach for the study of polysulfides' equilibria. Environ Sci Technol 2004, 38:6633-6644.

40. Kamyshny A Jr, Gun J, Rozkov D, Voitsekovski T, Lev O: Equilibrium distribution of polysulfide ions in aqueous solutions at different temperatures by rapid single phase derivatization. Environ Sci Technol 2007, 41:2395-2400.

41. Kamyshny A Jr: Solubility of cyclooctasulfur in pure water and sea water at different temperatures. Geochim Cosmochim Acta 2009, 73:6022-6028.

42. Kamyshny A Jr, Ekeltchik I, Gun J, Lev O: Method for the determination of inorganic polysulfide distribution in aquatic systems. Anal Chem 2006, 78:2631-2639.

43. LaMer $\mathrm{V}$, Dinegar $\mathrm{RH}$ : Theory, production and mechanism of formation of monodispersed hydrosols. J Am Chem Soc 1950, 72:4847-4854.

44. Steudel R: Mechanism for the formation of elemental sulfur from aqueous sulfide in chemical and microbiological desulfurization processes. Ind Eng Chem Res 1996, 35:1417-1423.

45. Kamyshny A Jr, Ferdelman TG: Dynamics of zero-valent sulfur species including polysulfides at seep sites on intertidal sand flats (Wadden Sea, North Sea). Mar Chem 2010, 121:17-26.

46. Kleinjan $W E$, de Keizer $A$, Janssen $A J H$ : Equilibrium of the reaction between dissolved sodium sulfide and biologically produced sulfur. Coll Surf B: Biointerfaces 2005, 43:228-237.

47. Prange A, Chauvistré R, Modrow H, Hormes J, Trüper HG, Dah C Quantitative speciation of sulfur in bacterial sulfur globules: X-ray absorption spectroscopy reveals at least three different species of sulfur. Microbiol 2002, 148:267-276.

48. Baker JE, Capel PD, Eisenreich SJ: Influence of colloids on sediment-water partition coefficients of polychlorobiphenyl congeners in natural waters. Environ Sci Technol 1986, 20:1136-1143.

49. Steudel $\mathrm{R}$, Holdt $\mathrm{G}$ : Solubilization of elemental sulfur in water by cationic and anionic surfactants. Angew Chem Int Ed Engl 1988, 27:1358-1359.

50. Tarasevich Yu I, Dolenko SA, Trifonova MY, Alekseenko EY: Association and colloid-chemical properties of humic acids in aqueous solution. Colloid $J$ 2013, 75:207-213.

51. Horzempa LM, Helz GR: Controls on the stability of sulfide sols; colloidal covellite as an example. Geochim Cosmochim Acta 1979, 43:1645-1650.

52. Kamyshny A Jr, Zilerbrand M, Ekeltchik I, Voitsekovski T, Gun J, Lev O: Speciation of polysulfides and zerovalent sulfur in sulfide-rich water wells in southern and central Israel. Aquat Geochem 2008, 14:171-192.

53. Schwarzenbach G, Fischer A: Die Acidität der Sulfane und die Zusammensetzung wässeriger Polysulfidlösungen. Helv Chim Acta 1960, 43:1365-1390

54. Liu X, Sprik M, Cheng J: Hydration, acidity and metal complexing of polysulfide species: a first principles molecular dynamics study. Chem Phys Letts 2013, 563:9-14.

55. Cloke PL: The geologic role of polysulfides_Part I The distribution of ionic species in aqueous sodium polysulfide solutions. Geochim Cosmochim Acta 1963, 27:1265-1298.

56. Davison W: The solubility of iron sulphides in synthetic and natural waters at ambient temperature. Aquatic Sci 1991, 53:309-329.

57. Hunger S, Benning LG: Greigite: a true intermediate on the polysulfide pathway to pyrite. Geochem Trans 2007, 8. doi:10.1186/1467-4866-8-1. 
58. Landing WM, Lewis BL: Thermodynamic Modeling Of Trace Metal Speciation In The Black Sea. In Black Sea Oceanography. Edited by Izdar E, Murray JW. Dordecht: Kluwer Academic Publishers; 1991:125-160.

59. Cutter GA, Kluckhohn RS: The cycling of particulate carbon, nitrogen, sulfur, and sulfur species (iron monosulfide, pyrite, and organic sulfur) in the water columns of Framvaren Fjord and the Black Sea. Mar Chem 1999, 67:149-160.

60. Li X, Cutter GA, Thunell RC, Tappa E, Gilhooly WP III, Lyons TW, Astor Y, Scranton Ml: Particulate sulfur species in the water column of the Cariaco Basin. Geochim Cosmochim Acta 2011, 75:148-163.

61. Landing WM, Westerlund S: The solution chemistry of iron(II) in Framvaren Fjord. Mar Chem 1988, 23:329-343.

62. Wilkin RT, Barnes HL: Formation processes of framboidal pyrite. Geochim Cosmochim Acta 1997, 61:323-339.

63. Berner RA: Thermodynamic stability of sedimentary iron sulfides. Amer J Sci 1967, 265:773-785.

64. Rickard D, Morse JW: Acid volatile sulfide (AVS). Mar Chem 2005, 97:141-197.

65. Siponen MI, Legrand $\mathrm{P}$, Widdrat $\mathrm{M}$, Jones SR, Zhang $\mathrm{W}$-J, Chang MCY, Faivre $D$, Arnoux P, Pigno D: Structural insight into magnetochrome-mediated magnetite biomineralization. Nature 2013, 502:681-684.

66. Li X, Taylor GT, Astor Y, Scranton MI: Relationship of sulfur speciation to hydrographic conditions and chemoautotrophic production in the Cariaco Basin. Mar Chem 2008, 112:53-64.

67. Morris JC, Stumm W: Redox Equilibria And Measurements Of Potentials In The Aquatic Environment. In Equilibrium Concepts in Natural Water Systems. Chap 13 American Chemical Society Advances in Chemistry Series: Chap 13 American Chemical Society Advances in Chemistry Series, 67; 1967:270-285.

68. Allen $\mathrm{P}$, Hickling A: Electrochemistry of sulfur. I. Overpotential in the discharge of the sulfide ion. Trans Faraday Soc 1957, 53:1626-1635.

69. Berner RA: Electrode studies of hydrogen sulfide in marine sediments. Geochim Cosmochim Acta 1963, 27:563-575.

70. Boulègue J, Michard G: Sulfur Speciations And Redox Processes In Reducing Environments. In Chemical Modeling in Aqueous Systems. Edited by Jenne EA. Washington DC, USA: American Chemical Society Symposium Series 93; 1979:25-50.

71. Wagman DD, Evans WH, Parker VB, Schumm RH, Halow I, Bailey SM, Churney KL, Nuttall EL: The NBS tables of chemical thermodynamic properties. J Phys Chem Ref Data 1982, 11(Supple 2). 2-1-2-392.

72. Boulègue J, Ciabrini J-P, Fouillac C, Michard G, Ouzounian G: Field titrations of dissolved sulfur species in anoxic environments-Geochemistry of Puzzichello waters (Corsica, France). Chem Geol 1979, 25:19-29.

73. Neretin LN, Böttcher ME, Grinenko VA: Sulfur isotope geochemistry of the Black Sea water column. Chem Geol 2000, 200:59-69.

74. Goyet C, Bradshaw AL, Brewer PG: The carbonate system in the Black Sea. Deep-Sea Res 1991, 38(Supple 2):S1049-S1068.

75. Luther GW III: Sulfur And lodine Speciation In The Water Column Of The Black Sea. In Black Sea Oceanography. Edited by Izdar E, Murray JW. Boston MA, USA: Kluwer Academic Publishers; 1991:187-203.

76. Richards FA: Anoxic Basins and Fjords. In Chemical Oceanography. Edited by Riley JP, Skirrow G. New York: Academic; 1965:611-645.

77. Jørgensen BB, Fossing H, Wirsen CO, Jannasch HW: Sulfide oxidation in the anoxic Black Sea chemocline. Deep-Sea Res 1991, 38(Supple):S1083-S1103.

78. Luther GA Jr, Church TM: Seasonal cycling of sulfur and iron in porewaters of a Delaware salt marsh. Mar Chem 1988, 23:295-309.

79. Boulègue J: Equilibria in a sulfide rich water from Enghien-les-Bains. France Geochim Cosmochim Acta 1977, 41:1751-1758.

80. Wang F, Tessier A, Buffle J: Voltammetric determination of elemental sulfur in pore waters. Environ Sci Technol 1998, 43:1353-1361.

81. Boulègue J, Lord SJ III, Church TM: Sulfur speciation and associated trace metals $(\mathrm{Fe}, \mathrm{Cu})$ in the pore waters of Great Marsh, Delaware. Geochim Cosmochim Acta 1982, 453-464

82. Hall KJ, Northcote TG: Conductivity-temperature standardization and dissolved solids estimation in a meromictic saline lake. Can J Fish Sci 1986, 43:2450-2454

83. Overmann J, Beatty JT, Krouse HR, Hall KJ: The sulfur cycle in the chemocline of a meromictic salt lake. Limnol Oceanogr 1996, 41:147-156.

84. Thamdrup B, Finster K, Würgler H, Bak F: Bacterial disproportionation of elemental sulfur coupled to chemical reduction of iron and manganese. Appl Environ Microbiol 1993, 59:101-108.

85. Poser A, Lohmayer R, Vogt C, Knoeller K, Planer-Friedrich B, Sorokin D, Richnow $\mathrm{H}-\mathrm{H}$, Finster $\mathrm{K}$ : Disproportionation of elemental sulfur by haloalkaliphilic bacteria from soda lakes. Extremeophiles 2013, 17:1003-1012.
86. Amrani A, Turner JW, Ma Q, Tang Y, Hatcher PG: Formation of sulfur and nitrogen corss-linked macromolecules under aqueous conditions. Geochim Cosmochim Acta 2007, 71:4141-4160.

87. Poulton SW, Krom MD, Raiswell R: A revised scheme for the reactivity of iron (oxyhydr)oxide minerals towards dissolved sulfide. Geochim Cosmochim Acta 2004, 68:3703-3715.

88. Holmkvist L, Kamyshny A, Vogt C, Vamvakopoulos K, Ferdelman TG, Jørgensen BB: Sulfate reduction below the sulfate-methane transition in Black Sea sediments. Deep-Sea Res / 2011, 58:493-504

89. Yücel M, Konovalov SK, Moore TS, Janzen CP, Luther GW III: Sulfur speciation in the upper Black Sea sediments. Chem Geol 2010, 269:364-375.

90. Li X, Gilhooly WP, Zerkle AL, Lyons TW, Farquhar J, Werne JP, Varela R, Scranton MI: Stable sulfur isotopes in the water column of the Cariaco Basin. Geochim Cosmochim Acta 2010, 74:6764-6778.

91. Goulet RR, Holmes J, Page B, Possant L, Siciliano SD, Lean DRS, Wang F, Mayot M, Tessier A: Mercury transformations and fluxes in sediments of a riverine wetland. Geochim Cosmochim Acta 2007, 71:3393-3406.

92. Stefánsson A, Seward TM: Experimental determination of the stability and stoichiometry of sulphide complexes of silver(l) in hydrothermal solutions to $400^{\circ} \mathrm{C}$. Geochim Cosmochim Acta 2003, 67:1395-1413.

93. Cutter GA: Dissolved arsenic and antimony in the Black Sea. Deep-Sea Res 1991, 38(38(Suppl. 2)):S825-S843.

94. Andreae $\mathrm{MO}$, Froelich PN Jr: Arsenic, antimony and germanium biogeochemistry in the Baltic Sea. Tellus 1984, 36B:101-117.

95. Aurillo AC, Mason RP, Hemond HF: Speciation and fate of arsenic in three lakes of the Aberjona Watershed. Environ Sci Technol 1994, 28:577-585.

96. Hollibaugh JT, Carini S, Gürleyük H, Jellison R, Joye SB, LeCleir G, Meile C, Vasques L, Wallschläger D: Arsenic speciation in Mono Lake, California: Response to seasonal stratification and anoxia. Geochim Cosmochim Acta 2005, 69:1925-1938.

97. Dahl TW, Chappaz A, Fitts JP, Lyons TW: Molybdenum reduction in a sulfidic lake: Evidence from X-ray absorption fine-structure spectroscopy and implications for the Mo paleoproxy. Geochim Cosmochim Acta 2013, 103:213-231.

98. Benning $L G$, Wilkin RT, Barnes HL: Reaction pathways in the Fe-S system below 100 degrees C. Chem Geol 2000, 167:25-51.

doi:10.1186/s12932-014-0013-x

Cite this article as: Helz: Activity of zero-valent sulfur in sulfidic natural waters. Geochemical Transactions 2014 15:13.

Publish with ChemistryCentral and every
scientist can read your work free of charge
"Open access provides opportunities to our
colleagues in other parts of the globe, by allowing
anyone to view the content free of charge."
W. Jeffery Hurst, The Hershey Company.
- available free of charge to the entire scientific community
- peer reviewed and published immediately upon acceptance
- cited in PubMed and archived on PubMed Central
- yours - you keep the copyright
Submit your manuscript here:
http://www.chemistrycentral.com/manuscript/

